Portland State University

PDXScholar

\title{
A study of runaways from six residential treatment agencies
}

\author{
Loris Colbath \\ Portland State University \\ Carolyn Krugel Graf \\ Portland State University \\ Carol McKinnon \\ Portland State University \\ Jean NewComb \\ Portland State University
}

Follow this and additional works at: https://pdxscholar.library.pdx.edu/open_access_etds

Part of the Child Psychology Commons, Social Welfare Commons, and the Social Work Commons Let us know how access to this document benefits you.

\section{Recommended Citation}

Colbath, Loris; Krugel Graf, Carolyn; McKinnon, Carol; and NewComb, Jean, "A study of runaways from six residential treatment agencies" (1975). Dissertations and Theses. Paper 1762.

https://doi.org/10.15760/etd.1761

This Thesis is brought to you for free and open access. It has been accepted for inclusion in Dissertations and Theses by an authorized administrator of PDXScholar. Please contact us if we can make this document more accessible: pdxscholar@pdx.edu. 


\title{
A STUDY OF RUNAWWAYS FROM SIX RESIDENTIAL TREATMENT AGENCIES
}

\author{
by \\ Loris Colbath \\ Carolyn Krugel Graf \\ Carol McKinnon \\ Jean Newcomb
}

A Report Submitted in Partial Fulfiliment of the Requirements for the degree of

\author{
Master \\ of \\ Soctal Work
}

Portland State UnIversity

1975 
The members of the committee approve the report of Lorls Colbath, Carolyn Krugel Graf, Carol McKinnon and Jean Newcomb, June 2, 1975.

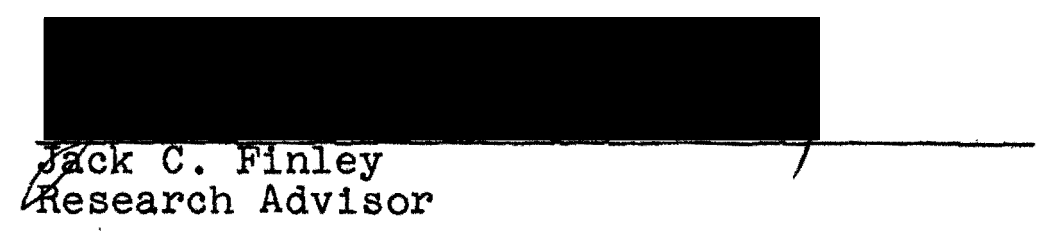

Dean of the School of Soclal Work 


\section{ABSTRACT}

The purposes of this study were: (1) to examine a select sample of both runaways and nonrunaways at six Oregon residential treatment facilities; (2) to determine the amount and type of preplacement visitation and counseling done within these agencies; (3) to determine the effect preplacement visitation and counseling has upon the studied sample of munaways and nonrunaways in decreasing or controlling the number of runs from the agencies involved; and (4) to determine significant characteristics between runaway and nonrunaway populations .

Testing materials included a two-part questionnaire, part of which was developed with girls from one of the participating agencies.

Running, which today is looked upon as a status offense, is costly in the effect it has upon the mind and emotions of the young runners, as well as the effect it has upon the budgets of the agencies involved. Running from a residential treatment program is also disruptive to the treatment plan which has been set up for that particular youth.

The work which has been done to date in this area is sketchy and incomplete. It does not clearly tell us whether 
or not preplacement counseling actually reduces the desire to run and helps to create a more comfortable atmosphere for the teen-ager.

Our sample consisted of both runners and a random sample of nonrunners from the participating agencies for the month of october. 
TABLE OF CONTENTS

CHAPTER

PAGE

I. INTRODUCTION . . . . . . . . . . . . . . . I 1

Narrat1ve . . . . . . . ....... 1

Objectives and Expected Significance

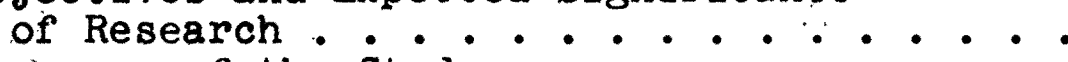

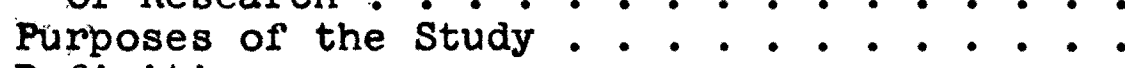

Definitions . . . . . . . . . . . . . .

Delimitations

II. REVIEW OF THE LITERATURE . . . . . . . . . 5

III. METHODOLOGY . • . . • • . • . . . . . . 19

Subjects . . . . . . . . . . . . 19

Instrument . . . . . . . . . . . . . 20

Procedure ................... . 20

Data Processing . . . . . . ....... 22

IV. DESCRIPTION OF PARTICIPATING AGENCIES . . . . . 23

V. PRESENTATION AND INTERPRETATION OF

DATA . . . . . . . . . . . . 34

Summary . • . . . . . . . . . . . 59

VI. SUMMARY OF RESULTS .. . . . . . . . . . . 72

Summary of Methodology . . • . : . . . :
Implications and Recommendations $\cdot 75$

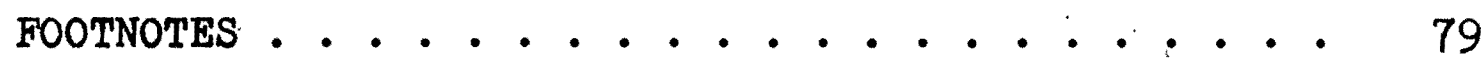

BIBLIOGRAPHY . . . . . . . . . . ... . . 81

APPENDICES . . . . . . . . . . . . . . . 85 


\section{LIST OF TABLES}

TABLE

PAGE

1. Number of Subjects who Ran October, 1974 According to Agency . . . . . . . . . 35

2. Cholce in Placement . . . . . . . . . . 36

3. Similarity of Placement to Expectations . . . 38

4. Preplacement Visitation . . . . . . . . 39

5. Preplacement Counseling . . . . . . . . . 40

6. Mean Age in Years According to Agency . . . . 42

7. Males and Females in Sample According to Agency . . . . . . . . . . . . 4 43

8. Mean Helghts and Weights According to Agency ............ . . . . 44

9. Place of Residence According to Agency . . . 45

10. School Achievement . . . . . . . . . . 46

11. School Attendance . . . . . . . . . . . . 47

12. Marital Status of Parents . . . . . . . 48

13. Adoption . . . . . . . . . . . . 49

14. Mean Number of Placements Per Agency . . . . . 50

15. Average Number of Weeks Spent in Placements Other than Home... . . . . . . 51

16. Who Accompanied Subjects to Placement ... . . 52

17. Family's Att1tude Toward Placement. . . . . 52

18. How Subjects Felt About Placement . . . . . 53

19. Who Subjects Talked W1th F1rst . . . . : . . 54 
20. How Welcome Subjects Felt . . . . . . . 54

21. Existence of a Buddy Program . . . . . . 55

22. How Often Caseworkers Have Visited Subjects ............ 56

23. How Often Subjects Would Like Caseworkers to Visit ......... 57

24. Subjects Runs From The1r Homes ....... 58

25. Other Family Member Runaways ........ 59

26. Mean Responses to Questions of When Subjects are Most Likely to Run and Where They are Most Likely to Run to.......... 68 
CHAPTER I

INTRODUCTION

\section{Narrative}

This practicum is an outgrowth of a request made by Orvilie Garrison, M.S.W. of Catholic Children's Services for research concerning teen-age runaways. Catholic Ch11dren's Services has, since 1971, been conducting a program dealing with acutely delinquent children who have been referred to them by court commitment. Runaways are felt to be a problem of real importance to the agency. This same condition exists in the other participating agencies and is considered by each of them to be a major problem.

Six oregon residential treatment agencies agreed to cooperate in this research project. They include:

1. Loulse Home

2. Villa St. Rose

3. Christie School for Girls

4. St. Mary's Home for Boys

5. Children's Farm Home

6. Catholic Children's Services

For the purposes of this study, a runner shall be dePined as absent from the agency for a period of more than twelve hours without the permission of the staff. 
Object1ves and Expected Significance

of Research

The research will attempt to fulfill the following purposes and objectives:

1. To determine the effect precounseling and preplacement visitation to the agency has on the rate of youths running from the agencies after placement.

2. To assist in developing criteria by which future runners can be 1dentifled.

3. To publish and distribute to the appropriate residentlal treatment agencies the results of this research.'

It is anticipated that this research will:

1. Provide a base of information for the development of soclally significant programs to deal with both past and future runaways.

2. Provide information from runaways themselves which heretofore has not been shared with counselors and soclal work agencies.

3. Assist in reducing the actual dollar amount presently being expended by the participating agencies in handling the runaway problem.

Purposes of the Study

The purposes of this study were: 
1. To examine a select sample of both munaways and nonrunaways at six Oregon social work agencles.

2. To determine the amount and type of preplacement visitation and counseling done within these agencles.

3. To determine the effect preplacement visitation and counseling has upon the studied sample of runaways and nonrunaways in controlling or decreasing the number of "runs" from the agencies involved.

\section{Definitions}

The following definitions are to clarify the meaning of specific terms that are used throughout the study:

Runaway.--A youth between the ages of eleven and seventeen who was absent from the agency for a period of more than twelve hours w1thout the permission of the staff.

Nonmunaway. --A youth in residential care between the ages of eleven and seventeen who did not run from the agency during October, 1974.

Agency.--A residential social service organization providing programs to meet the soctal and emotional needs of persons within a community. These organizations have community sanction for their operation. 
Significant difference.--A statistical difference which results in a .05 level of probability.

\section{Delimitations}

This study was exploratory and, therefore, primarily descriptive with respect to the problem of the amount and type of preplacement visitation and counseling done when placing a teen-ager in an agency, and its effect upon the runaway rate.

The primary focus of this study was to look at six residential treatment agencies within oregon and their services to teen-agers prior to placement within these agencies.

The study primarily involved geographic boundaries of the Portland, Oregon area, with the exception of the Children's Farm Home which is located some elghty-five miles south of Portland, Oregon in a rural setting near Corvallis, Oregon. Specifically, the sample population of this study consisted of fifty children from age eleven to seventeen who were residents at the participating social work agencies. They were court committed to these agencies. The study was confined to teen-agers who ran during the month of october, 1974 . 


\section{CHAPTER II}

\section{REVIEW OF THE LITERATURE}

While there is much research in the literature relating to runaways, most of it is not directiy relevant to this study. Children in residential facilities, such as the particlpating agencles, have already come to the attention of the authorities. Most of the literature is concerned with the runaway from home, and the cultural, soclal and psychological dynamics of his/her running. Nonetheless, we have done a brief survey of the literature because of the overlapping nature of the population, showing common factors attributed to the phenomenon of running away.

We shall first discuss some of the research material from the literature, more in view of 1 ts general rather than direct relevance to our study.

Most notable among contributing factors to the phenomenon of running away is the aspect of cultural change since the late sixtles. From U.S. News \& World Report (1972), 1 a feature article reporting on runaways in the country's major cities states that more than ten thousand children run away weekly. The patterns and numbers had markedly changed by the early seventies: many more girls were included in the numbers (almost equal to boys), the average age had 
diminished (between thirteen and seventeen years old, though some as young as ten), and the destination was no longer to the distant large urban areas but now of ten to the closest metropolitan center.

Three important cultural conditions seem to have been responsible for the declsion of more and more young people to run. First, the "youth culture" influenced by television and youth orlented publications has made running away a socially acceptable alternative: These media have as much as included "do-1t-yourself" Instructions of how to run and where to go. Secondly, with the shift of focus away from: the largest cities to smaller towns nearby, the opportunity has become more avallable to the less daring. Now every urban center has sheltering communes or public agencies that accommodate the runner, of fering "Instant fellowship and protection." Lastly, we have seen a continuing loosening of the family ties. The young have had to depend entirely upon the nuclear family which has become increasingly less stable as a result of divorce and mobllity.

Many researchers have attempted to measure the relationship of munning with soclal deviancy. The soclal 1mplications of running away from home are discussed in a study by Bradshaw, et al. $(1969)^{2}$ in Salt Lake County; Utah. They found that 60 per cent of their runner sample (referrals from juvenile court) had had previous juvenile records. 
Notable events preceding the runs were: trouble with parents, problems with school or conflicts with other relatives. In 75 per cent of the incidents, difficulties within the home were named as the major problem. Although a very large part of the sample reported having been troubled with personal problems for a period of six or more months, 63 per cent sald that they had recelved no help in solving them. Hildebrand $(1963)^{3}$ asserts that runaways represent young persons who have a problem but have usually not yet developed a definite antisocial attitude. He goes on to conclude that running is a strong indication of family problems and that with intervention, the young person may be deterred from more serious acting out behavior.

Another study that attributes running behavior as predictive of future delinquency is that of Ivan Nye and James Short (1957). 4 Their sample population $(2,350)$ was derived from normal high school students from several sections of the country and from residents of boys' training schools. They constructed a twelve item scale of antisocial and criminal behaviors. Running away was found to be the first item to occur in less than 10 per cent of high school population, while it occurred in 61 per cent of the training school population. This then provided a cut-off point between the populations and appeared to be a significant behavior that was related to more serlous delinquency. 
Shellow, et al. (1967), ${ }^{5}$ comment that previous studies have defined running away as elther soclally deviant or personally pathological. They felt that such definitiveness resulted from the kinds of agency or group from which the sample was selected. Since they were anxious to choose a sample from a more general group, they selected 776 young people reported missing to the pollce over the perlod of a year. The resultant characteristics were noted as follows: they traveled short distances, rarely beyond their own metropolitan area, returning within forty-elght hours of their own volition, and ran as often with others as they did alone. Two-thirds had experienced trouble in school, and a greater proportion had come from broken homes. ". . school records show that runaways.. - were absent from school more often and had lower grades." ${ }^{6}$ of those questioned who had not run, when asked if they had seriously thought of dolng so, one out of three sald yes.

As a result, these authors advise caution in designating specific characteristics to runaways. They concluded] that often the deciding factor in the decision to run may very well be the 1mmediate clrcumstance. They do draw some conclusions from thelr data. Dividing the runaways into two groups, they are able to characterize the first "as being relatively small . . for whom running away was intimately bound up with individual or family pathology"; 7 and the 
second, much larger group, most of whom had run only once. This group, with some differences more closely resembled the nonrunners, rather than being similar to the serlously disturbed population of the smaller group. The recommendation coming from this data was in the treatment plan: For the first group they prescribed special care for the sever1ty of their personal pathology, and for the second group they suggested treating them in ways similar to normally troubled adolescents.

This brings us to consider some of the psychodynamic factors that have been projected by a number of writers. Both of the studies executed by Amos Robey, et al. (1964), 8 and Vedder, et al. (1970), 9 percelved the oediphal conflict as belng the precipitant factor in girls' muning away. It has been hypothesized that they are resisting the domination of the mother and are fearful of an incestuous relationship with the father. Randall Foster (1962) 10 concurs, saying "sublimation of incestuous w1shes... for the child with Iimited abilities to cope with dangerous impulses, can lead her to run to escape temptation and search for safer grat1fication."

Robey concludes from his study of forty-two runaway girls taken from court cases, that "running away is a complex neurotic interraction between the parents and the daughter in a triangle situation."1l Fredrick Rosenheim 
$(1940)^{12}$ regards the oediphal conflict as present in the reasons for boys running as well. He says that it is a form of "self-banishment" from the home, away from the dangerous impulse toward the mother and the struggle with the father. 13

Robey goes on to say that placement in foster homes or in an institution is usually not adequate to control the girl's behavior, unless it is combined with treatment in consideration of the dynamics and needs of the girl, - . severe acting out in terms of further running away attempts, flounting of authority despite disciplinary action may continue to occur . . . often a return home (from the placement) will reactivate the situation. 14

Theodore Leventhal $(1964)^{15}$ saw a measure of difference between the capacity for "Inner control" of the runner as compared to the nonrunner. His study of forty-two runners and a like number of nonrunners was judged on those manifestations of uncontrol. His rating criteria for uncontrol was: (1) discharge type of behavior; e.g., bed wetting, impulsivity and temper tantrums, (2) deficlent mechanisms regulating behavior, such as judgement, cognition and mobllity, and (3) a self-1mage of helplessness and inability to control. 16 His results indicated that minaways man1fested these characteristics to a greater extent than nonrunners. Other behaviors found to be assoclated with running away were: stealing, truancy, demanding behavior, 
1rresponsibllity about time, susplciousness and poor physical coordination. Also significant was the fact that onethird of the munaways verbalized their feelings of lack of control, and that in therapy sixteen of them sald that their main concern was the lack of control of their impulses and their feelings of helplessness over external events.

Repeated throughout the literature are the problems of the adolescent with his/her family. In many cases the stablilty of the home has already been interrupted and the child feels refected, helpless and angry. His/her way of coping is to flee. The other situation which he/she may view as dangerous is the incestuous impulse of the opposite sexed parent and the domination by the like sexed parent. Again, if he/she does not have the coping devices to deal with his/her fear, anger or frustration, his/her recourse is flight or fight. The findings of Blood and D'Angelo (1974), 17 confirm this phenomenon: "Whenever signiflcant areas of conflict arise . . and confrontation ensues between the adolescent and the parent, the adolescent may resort to filght."18 Major issues and conflict are considered to come from difficulties arising from the frustration of the basic needs; v1z., acceptance, achievement, recognition, affection, belongingness, conformity to peers and attainment of worthy goals. Affection and acceptance proved to be the key 1ssues of conflict but the authors 
suggest that the issues can be reduced to noncummunication; without the abillty to express one's self and to be listened to, there is no real sense of acceptance, love or worth. They further make the point from the findings of the ohio State's Teen-age Flight Project, ${ }^{19}$ that runaways experience almost three times as much physical abuse, suggesting that there is an avoidance of communication on the part of their parents.

Moving now to the literature that is directly assoclated with the runner who has been institutionalized, Street, et al. $(1966)^{20}$ did a comparative study on the effects of different organizational models and treatment modalities on the inmates of six boys' correctional institutions. Records were kept on the proportion of inmates who had run one or more times. The two institutions where the treatment model was structured for obedience and conformity with strong internal sanctions had 16 per cent and 20 per cent runners. The two facilities which were considered to be mental health treatment orlented--stressing a therapeutic milieu, a policy of frequent home visits (to let off steam), attending school away from the residence and using threats of transfer to a harsher facility--had only 10 per cent and 16 per cent runners. The remaining two residential facilities stressed nelther custodial care nor treatment but were orlented to re-education and development, being struc- 
tured to a full program of work, school and recreation. Here, running away was considered to be normally symptomatic and rather irrelevant. The proportion of their munners was the highest with 29 per cent and 50 per cent.

The overall consequences of the different organizations and modalities showed that none of the institutions was truly successful at "producing changes appropriate to the lives the inmates would lead outside."2l However, the treatment facility using the mllieu therapy appeared to have the most positive effect, with greater development of personal and social controls, and some skills in problem solvIng and self-understanding.

McCorkle, reporting on the "Highfields," a unique treatment center in the New Jersey System of Corrections, says that troubled youthful offenders need an informal, easy learning experience in a certain type of social m1lieu. 22 The basic values of such an atmosphere are security, flexibility and nonpunitive, nonaggressive attitudes on the part of the staff. In this small residential facility, housing twenty boys with serious delinquency records, there are only two imposed rules: that no boys shall speak to the women at the hospital in which they work part time, and secondly that no boy shall leave the grounds without belng accompanied by a staff person. All other rules are made by staff 
and boys together and enforced by both. Indoctrination is done entirely by the peer group in an informal way.

About the specific problem of running away: for marginal infractions; that is, occasional testing of the mile, the peer group is likely to handle the consequence or at worst, the offender gets a heavier work detail. For an actual escape the only recourse is the very strong sanction of going to a harsher security institution. By giving a boy the opportunity to test the adult role in such an informal flexible setting, he can with understanding and more knowledge, accept the adult as a less hostile and threatening figure. Consequently, his hostile and aggressive impulses toward both adults and peers are lessened. He is then able to turn willingly for guidance and the formallty of rules and indoctrination is exchanged for learning by example. Therefore, acting out by running away is not a primary problem at the Highfields.

Gisela Konopka $(1966)^{23}$ expresses criticlsm of the workers in institutions for girls. She states that they are often nalve, coming from sheltered backgrounds; they start out with unrealistic idealism and become thwarted and dis11lusioned, frightened and unsure of themselves. When this change takes place, from being ardent and well-meaning to hardened and distrusting, the worker often presumes that the girl is "fronting" or "doing a snow job." It then becomes 
Impossible for the girl to be accepted in her full potential. When workers are unprepared for the hostility and distrust that the girl brings with her, they are fearful themselves and retaliate by "hitting out" or "getting on a power trip." Such interraction only increases the anger, frustration and impulse to flee. The author recommends that services to young people in such facilities need re-examination and that a continuium of service should be undertaken, providing help and information while the troubled youth is still at home, at the foster home and small faclitty.

Suggestions from the National Conference of Superintendents of Tralning Schools on more successful ways of recelving and orlenting the young person into the institution may be instrumental in cutting down the runing rate. 24 Initially they suggest greeting and welcoming without laying down rules or searching the person, immediately providing some recreational activity to avold physical idleness, and providing a place to maintain their personal property without its being interfered with by staff or peers.

They pose five ways in which orlentation procedures may be made more successful: (I) giving the newcomer a favorable but honest impression of the program and its purposes, (2) enabling $\mathrm{h} 1 \mathrm{~m} / \mathrm{her}$ to have all of the facts so that he/she may participate in planning for himself/herself, (3) allowing several weeks for adjustment, (4) using group 
discussion methods in orientation, and (5) giving him/her an opportunity to question staff on the "whys" of what's happening. 25

They further recommend that rules and restrictions be constantly evaluated for their harshness and ineffectiveness. Such rules are often the sources of the acting out behavior (e.g., runing) which interfere with the treatment of the deeper problem. Anger and frustration at what seems to be unreasonable rules may reactivate a deep-seated anxlety by re-creating the original conflict situation. Discipline should be with the understanding that frequently his/her psycho-social behavior pattern has led the child into conflict with authority. The school or institution represents the same hostile environment that he/she has had to fight against. The decision to flee or fight is ever present in his/her alternatives of coping behavior.

In summary, the literature as it relates to our study Indicates several (or a combination of) reasons that may be responsible for young people running away. Communication through popular media of the new life styles has made running away an acceptable alternative. For those who are looking for a way out of their personal situation, the "how to" of running is readily avallable as is shelter and fellowship at their destination. 
One of the social implications revlewed in the literature is that as the family has become dysfunctional, the chlld has sought a way out of the tension and conflict of the home. Running as an alternative becomes repetitious behavior whenever the young person finds himself/herself in a similar situation of helplessness and anxiety. Further discussed was the fact that minning away is often the first act in the direction of delinquency, and is frequently assoclated with school problems, truancy and stealing.

The psychodynamic aspect of the young runaway is discussed in terms of the oediphal conflict. The reason for the young person's munning is hypothesized as his/her inabllity to cope with his/her dangerous 1mpulses toward the opposite sexed parent or the power struggle with the 11ke sexed parent. Also prominently discussed is the individual whose Inadequate impulse control leads him/her to use discharge behavior in 11 eu of judgment and cognition. Running away is h1s/her response to feelings of helplessness to control elther internal or external events.

The research on placement facilities proposed the need for earlier help for those being placed; preparation and participation in the cholces that are made for them. Recommendations were made for a ready source of information and help in problem solving in the first days and weeks of their 
placement: The atmosphere needs to be less threatening and the workers more appropriate in background to be able to relate more realistically to their charges. Most importantly, programs and regulations should be continuously checked for their value and reasonableness toward encouragIng growth and development of healthy aduits. 
CHAPTER III

METHODOLOGY

Our design is a descriptive analysis. The hypothesis was tested by survey research.

$\underline{\text { Subjects }}$

The subjects were drawn from Catholic Services, Ch11dren's Farm Home, Christie, Louise Home, St. Mary's Home for Boys, and V1lla st. Rose. All are resident1al treatment facilities within the state of Oregon. The agencies were chosen for their appropriateness to our study and their interest and willingness in cooperating with the study. The agencles are concerned with the problem of runaways and are Interested in information that might be produced from the study. All were given information on how the study would be administered and a copy of the questionnaire.

The runners were youth who were absent from the agency for a perlod of more than twelve hours without the perm1ssion of the staff during the month of October, 1974. The nonrunners were randomly chosen from youth who had not run during the month of october. The subjects included twentyf'ive runners and twenty-five nonmunners. The number of runners from an agency was matched with the same number of 
nonrunners from each agency. The subjects ranged in age from eleven to seventeen years.

Instrument

The instrument used was a two-part questionnaire. Part I was designed with input from the staff and youth placed in these agencles, plus the assumptions of the researchers. Of Part II, pages three, four, seven and elght were designed by girls from Villa St. Rose. Pages five and s1x of Part II were constructed by the researchers. The questions asked on the first part of the questionnalre were elther open ended, requiring a subjective answer, or closed ended requiring a speclfic cholce or specific answers. Part II of the quest1onnaire was composed of closed ended questions. Part I contained elght additional questions answered by runners only regarding a description of the current run.

Some minor revisions were made in the questionnaire following the pretest. A copy of the pretest interview questlonnalre is located in the Appendix, pages 86-88. A copy of the final questionnaire is included in the Appendix, pages $89-93$.

\section{Procedure}

The orlginal design included nine residential agencles; all but one were located in the Portland metropolitan area. These agencies were first contacted regarding their 
interest in participating in our research and asked for input into the questionnaire's design. Three of the agencies declined to participate because their populations were not appropriate for the research.

Letters were sent to the six agencies requesting a record of their munners for the month of October, 1974. The following month we contacted each agency for the numbers of runners and attempted to set up schedules with those runners and a like number of randomly selected nonrunners from each agency .

The intervlews were carried out by the authors with the exception of those at the Chlldren's Farm Home. It was the preference of the staff that one of their members administer the questionnaires. St. Mary's Home for Boys chose not to have the second part of the questionnaire administered to their boys. Other than those two exceptions, all of the interviewing was done by the authors. Each interview was conducted alone with the interviewee; introductions were made, explanation of the purpose of the research was given and confidentiality was assured. In Part $I$ the interviewer read the questions and wrote in the answers; in Part II the participant read and filled in his own answers. The questioner remained on hand to clarify when needed. The time to administer both parts of the questionnaire was approximately thirty minutes. Each interviewee was thanked and assured 
that he/she would be able to see the final results of the research.

\section{Data Processing}

The following statistics were used in computing Part I of the questionnaire as reported in presentation and interpretation of data.

The difference between two sample proportions was computed for various questions and then a $z$ score calculated. A chi-square was computed on appropriate questions using an alternate formula as follows:

$$
x^{2}=\frac{N\left(|A D-B C|-\frac{N}{2}\right)^{2}}{(A+B)(C+D)(A+C)(B+D)}
$$

A $t$ score was calculated for appropriate questions.

Various questions were open ended, requiring subjective responses. This data was not dealt with statistically but was described in an interpretative manner.

Data from Part II of the questionnalre was computed on the Honeywell computer, using a BMD program for factor analysis with a preliminary transgeneration to replace blank responses with the mean. Two factor analyses were run: the first with twenty-two variables from Part II, pages 1 and 2 of the questionnaire, and the second with thirteen variables from Part II, pages 7 and 8 of the questionnaire. 


\section{CHAPTER IV \\ DESCRIPTION OF PARTICIPATING \\ AGENCIES}

The following are descriptions of the agencles involved in the instant study. The descriptions include environment, population, referrals, treatment program, controls, policy toward runaways, average length of stay, pollcy of visitation and school.

Carroll House (Catholic Services) is located at 3725 Southeast 8oth Avenue, Portland, Oregon. The bullding is a one story L-shaped structure with seven individual bedrooms and a dormitory. A bedroom-sitting room-bath combination gives the houseparents private quarters. There is a large communal dining room, a recreation-library room, and a crafts room. A fence-enclosed patio provides a private recreation area.

The agency is licensed for ten girls between twelve and eighteen years of age. The girls are referred by the court through the Children's Services Division for munaway, beyond parental control, truancy, sex delinquencles, drinklng, drugs, conflicts with family and other antisocial behavior. The girls remain at Carroll House for seven to nine months. 
Twenty-four hour residential care is provided with schooling at Franklin High School, or a program individually planned. It is expected that the students will be involved in work experlences. If special school heip is needed, it is arranged and may involve completion of the General Education program. While utilizing community recreational resources, the program also includes planned activities within the center.

Such community resources as psychlatric and psychological services as needed are pald for on an individual basis. The agency also has the services of a consulting psychlatrist who may consult with the caseworker and houseparents or see the girls on an individual basis.

Casework dutles for individual and group counseling is the responsibility of the Catholic Services agency caseworker. Intervention in day by day living experiences is used to create a therapeutic situation. The girls' families become part of the caseworker's focus. The glrls are put on a level system when they enter the program and recelve privlleges according to the level they achieve. When a girl runs away, she will be brought back unt1l it is determined that the program is not meeting the needs of the child. Parents are invited to visit during the first two weeks. A day home visit can be planned on A level, weekend visits can be planned three weeks apart on B and C levels, every other 
weekend on $D$ level and every weekend on $E$ level with possibly a week at home for a trial perlod before discharge. Children's Farm Home is located at 4455 Northeast H1ghway 20, Corvallis, Oregon. Residences for boys and girls, a nondenominational chapel, school facilities, service buildings, and the administration building are bullt around an oval drive and cover ten acres. The farm operation includes a beef herd, horses and 4-H stock to meet the needs of children interested in an additional growth experience.

Forty-two boys and twelve girls live in four groups of ten to sixteen. Referrals are recelved from juvenile courts and Children's Services Divisions of each county. There are also private placements and referrals from other agencies such as Family Counseling, mental health clinics and school social service departments. The Farm Home responds to the needs of children for a residential center treating behavior problems of boys and girls between the ages of twelve and eighteen who are unable to live in their own homes because of family conflicts, emotional problems, or inability to function in the public schools. The average length of stay is thirty-two months for younger boys and eighteen to twentyfour months for older boys.

Most students attend the accredited junior or senior high school on the Farm Home grounds. The school program 
stresses development of basic learning skills and adjustment of attitudes toward school. A large faculty enables the school program to be geared to the achlevement level of each student. A few students attend Corvallis schools.

The treatment program includes group meetings regarding peer relationships and management problems. Four caseworkers are responsible for coordinating efforts of the staff, faculty, outside agencles and families. A psychologlst meets one full day weekly, providing diagnostic services and consultation to staff. Some treatment and diagnostic services are avaliable through Benton County Mental Health Clinic and the Corvallis school system. A psychiatrist administers a program that provides psychologically supportive drugs for those children who need temporary assistance to get them over a particularly traumatic period in their treatment. Basic to all treatment are the needs to create a secure, safe place for all students to live, an environment that reinforces appropriate social behavior, and an atmosphere in which to learn.

There is no regular policy for runaways. There are different policies for each of the four groups. The child's freedom might be 1 imlted within the home, he/she might have to be under constant supervision, or the chlld might have to sit on a chair in the living room for two or three hours. 
Work is not used as a punishment and the goal is to have the children see work as a positive activity.

Christle School is located in Marylhurst, Oregon. The campus covers about sixteen acres and is in a semirural environment. There are two cottages, each with a capacity for twenty girls and another small unit for five girls. The agency is licensed for fifty girls, nine to elghteen years of age, and admits girls between the ages of nine to thirteen and/or who academically have not completed elghth grade.

The majority of children are referred by Children's Services Division; other referrals come from school social workers, mental health agencles and parents. It is designed to provide treatment for girls who are unable to live successfully at home or in foster homes because of emotional maladjustment problems in interpersonal relationships, and/or major social difficulties in school or in the community. If a girl remains in the program beyond three to six months, the usual length of stay may vary from nine to elghteen months.

The school program attempts to provide each girl with an optimal learning situation based upon individual needs. Attention is given to encourage successful approaches to learning, study habits, and rational thought processes so that the girls may become increasingly independent in the school setting. 
Clinical services include counseling with child and family by social work staff. Psychịatric, psychological and medical services are also avallable on an ongolng basis approprlate to the needs of the child and the resources of the agency. The treatment approach involves the assignment of members of various disciplines to be responsible for planning and carrying out together the program and treatment for a specific child or speciflc group of girls. The process of the team approach involves a constant sharing and integration of contributions from the different disciplines.

In treatment of runaways the general pollcy is to help prevent runs as much as possible by working on establishing relationships with girls. When girls run, a contact is established with local police departments, parents are not1fled as well as the referral source. Treatment following return from runs is individualized, and there is no predetermined set of consequences applicable to all girls.

Visits with parents are encouraged whenever it appears these have positive meaning to the child. "She can have weekly, biweekly, monthly, or no visits with family, depending upon the mutual planning with parental figures.

Louise Home (Albertina Kerr) is located at 722 Northeast 162nd Avenue in Portland, Oregon. The Kathryn Carlson Cottage contains three separate living units and houses 
thirty-five girls. The James Lakin Cottage serves fourteen girls.

The agency serves as a residential treatment facility for emotionally disturbed and delinquent girls, ages twelve through seventeen years.

The girls attend Wynn Watts School which is located on campus and is an integral part of the treatment program. The school program offers courses to complete graduation requirements under both the previous and revised oregon graduation standards. Classes are from ten to twelve students and many are individualized with each person working at her own rate.

The treatment program has been developed on the model of a therapeutic community utilizing the concepts of reality therapy. The program is arranged in such a way that it makes available for treatment purposes all relationships and all activities in the life of the girls in residence. The staff is able to adopt specific attitudes toward chlldren and to shape their environment to cope with their particular problems.

Albertina Kerr uses a team approach composed of a social worker and six child care workers. An attempt is made to evaluate the needs of each girl at the time she is accepted for placement and assign her to the treatment team that can best deal with her specific problems. The team has 
a choice of a variety of treatment modes, including: individual psychotherapy, peer group therapy, single family or multiple family group therapy. There are regular staff meetings and team meetings which make it possible to adjust or to reinforce treatment plans as they progress. Other agency resources such as the consulting child psychlatrist, may be utilized to assist, to evaluate and to adjust to ongoing treatment procedures.

There are no locked doors or environmental controls at Louise Home. Home visits can be made after the first month in residence. The family can make visits to the Home and others can visit with the staff's approval.

Runaways are taken back until it is determined that the program is not meeting their needs. The policy toward runaways is varied with each individual, according to their treatment plan. They may be welcomed with open arms or put on restriction.

St. Mary's Home for Boys is a residential facility located about twelve miles from the center of metropolitan Portland. The home is bounded by a busy highway on the south and surrounded by 450 acres of undeveloped land on the remalning three sides. There are two living cottages, classroom modules, an administration bullding and a gymnasium. There are no locked areas or fences for the purpose of keeping or deterring the boys from leaving, 
The school has an enrollment of forty-three boys. The officlal age range is from nine to seventeen years. However, the actual age 18 closer to ten to fourteen because it better fits the concept of the program. The cottages are divided by age; those under twelve years are placed together and those over twelve years are placed together. The length of stay is twelve to fourteen months.

The treatment modality used is behavior modification with a token economy. It is essentially based on a five phase target system, with target goals being initially set by the staff and progressing to personallzed goals set by the boy, his advisors and peers. Data is being collected continuously throughout the day, computerized nightly so that every individual is aware of points accumulated toward h1s present target.

The only controls used are gain or loss of privilege; no punishment is meted out for infraction of rules. If a boy runs away, he may be reduced to an earlier phase or lose all accumulated points. Occasionally an out-of-control boy is placed in the time-out room for a very brief period (e.8., minutes). The assaultive boy may be handled by removal from the school.

Most of the schooling takes place within the facility. However, some of the youngest boys go to an adjacent 
elementary school and the oldest, if academically successful, to the local funior high or high school.

V1lla St. Rose is located at 597 North Dekum Street in Portland, oregon. Villa is a large old bullding set up on a dormitory living basis. There are three units housing fifteen to seventeen girls each. Fifty-one girls of high school age are in residence. While the setting is basically open, there are some locked doors. The average length of stay is nine to twelve months.

The girls are referred to villa by the Children's Services Division and most have had previous contact with other soctal agencles.

The school program is accredited and able to grant a high school diploma. Most girls entering villa are two to four grades behind academically. The classes are small and geared to the individual's needs. A successful experience in the school setting is given high priority.

Basically the professional staff are soclal workers who provide individual, family and group treatment based on the needs of each girl admitted. A psychologist provides testing and consultation as needed. Psychiatric consultation as needed is provided by Delaney Mental Health Clinic. The basic treatment unit is a team approach (one for each living group). Teams are composed of the soclal worker, 
chlld care staff and two teachers who individualize programs for each girl through continuous evaluation and planning.

Runaways are accepted back into the program and are treated as new girls. They must re-earn all privileges they may have had. Runs are dealt with by the teams and living groups as unacceptable behavior.

Families are required to come for a meeting prior to home visits being granted. Home visits and family involvement are encouraged. After an initial period of three to six months, girls may have two home visits a month. 


\section{CHAPTER V}

\section{PRESENTATION AND INTERPRETATION OF DATA}

One of the main purposes of this study was to determine the amount and type of preplacement counseling and visitation received by runners and nonmunners. Besides questions relating specifically to counseling and visitation, a number of questions considered closely IInked to preplacement counseling and visitation were explored. Among these tangential questions are month subjects were placed, amount of cholce subjects had in being placed, what subjects had heard about placement, what subjects' expectations of placement had been, and how near the actual experlences were to the subjects' expectations.

The month of placement is an important bit of data in considering the basic hypothesis of this study. Part of the hypothesis being tested is that if adolescents are not given counseling that is directly concerned with their upcoming placement in an agency, they are more likely to run. A further assumption 1 s that subjects are higher runaway risks Immediately after placement if they do not recelve adequate preplacement counseling and previsitation. Since our runners were subjects who ran the month of october, the number 
of subjects placed during this month were tabulated and compared. Three runners and four nonrunners were placed in October. There is not a signiflcant difference between these two groups for the varlable of month of placement. Table 1 indicates the number of subjects from each agency placed in October, 1974.

\section{TABLE 1}

NUMBER OF SUBJECTS WHO RAN OCTOBER, 1974 ACCORDING TO AGENCY

\begin{tabular}{|c|c|c|c|c|c|c|}
\hline & Loulse & Villa & Christie & $\begin{array}{l}\text { St. } \\
\text { Mary's }\end{array}$ & $\begin{array}{l}\text { Ch11- } \\
\text { dren' } \mathbf{8} \\
\text { Farm }\end{array}$ & $\begin{array}{l}\text { Cath- } \\
\text { ollc } \\
\text { Chari- } \\
\text { ties }\end{array}$ \\
\hline Runners & 2. & 1 & 1 & 0 & 0 & 0 \\
\hline $\begin{array}{l}\text { Non- } \\
\text { runners }\end{array}$ & 0 & 0 & 2 & 0 & 0. & 1 \\
\hline
\end{tabular}

The cholce percelved by respondents in being placed in residential care was also considered a factor in preplacement preparation. It is assumed that adequate preplacement counseling would provide the counselor with some choice of agency or would increase subject's perception of having a choice in the decision-making process.

Table 2 indicates responses to the amount of choice subjects felt they had in belng placed. 
TABLE 2

CHOICE IN PLACEMENT

Number of Responses Per Category

\begin{tabular}{lcccccc}
\hline & None & $\begin{array}{l}\text { Very } \\
\text { Little }\end{array}$ & Some & A Lot & $\begin{array}{c}\text { Very } \\
\text { Much }\end{array}$ & $\begin{array}{l}\text { No } \\
\text { Response }\end{array}$ \\
\hline $\begin{array}{l}\text { Runners } \\
\begin{array}{l}\text { Non- } \\
\text { munners }\end{array}\end{array}$ & 9 & 6 & 5 & 0 & 3 & 2 \\
\hline
\end{tabular}

For statistical purposes, the data was combined in the following way:

$$
\text { None } \rightarrow \text { Very } \quad \text { Litie Some } \rightarrow \text { Very }
$$

\begin{tabular}{llc}
$\begin{array}{l}\text { Runners } \\
\text { Non- } \\
\text { runners }\end{array}$ & 15 & 8 \\
& 21 & 4 \\
\hline
\end{tabular}

A ch1-square value of 1.363 was calculated with one degree of freedom and a total $N$ of 48 . Th1s is below the critical value of 3.84 and is not signiflcant at the .05 level of significance. Therefore, amount of choice subjects felt 
they had in belng placed is not a signlficant difference between runners and nonrunners.

Subjects were asked what they had heard about their placement and what they expected it to be like. The responses to these open ended questions will be described in a general, interpretative way that is not statistically significant. Overall, nonrunners' expectations were much lower and more negative than the runners'. Nonrunners' responses were predominantly very negative; e.g., "lesblan place," "flghting," "people really mean," "prison," or neutral; e.g., "boarding school," "no boys," "OK place," "strict.". Runners' responses were generally extremely positive; e.g., "realiy good place," "horses and swimming pool," "pleasant place," "no work," "smoke any time," "a very good place for people like me." Several possible interpretations could be considered from these observations. Nonrunners appear to have a more negative or realistic plcture of their upcoming placement. This could mean they are better prepared to deal with the realities of institutional living, and in fact may find their placements much better than anticipated. Runners appear to have extremely high "pollyannalish" expectations for their placements. The inevitable disappointment inherent in this overly ldealized view could help trigger feelings assoclated with runaway behavior. 
Subjects were asked whether the placement was similar to what they expected. This data is displayed in Table 3.

\section{TABLE 3}

SIMILARITY OF PLACEMENT

TO EXPECTATIONS

Number of Responses Per Category

\begin{tabular}{lccc}
\hline & Yes & No & No Response \\
\hline $\begin{array}{l}\text { Runners } \\
\begin{array}{l}\text { Non- } \\
\text { runners }\end{array}\end{array}$ & 3 & 19 & 3 \\
& 7 & 14 & 4 \\
\hline
\end{tabular}

A ch1-square was computed and a score of 1.362 was obtalned with one degree of freedom and a total $N$ of 43 . This is below the critlcal value of 3.84 and is not signiflcant at the .05 level of significance. Hence no signiflcant difference was noted between groups for the variable of whether subjects' expectations matched the reality of their experlences in their placements.

Table 4 displays the responses to the question of whether subjects believed a preplacement visit would have helped them adjust to their new placement. 
TABLE 4

PREPLACEMENT VISITATION

Number of Responses Per Category

\begin{tabular}{lccc}
\hline & Yes & No & No Response \\
\hline $\begin{array}{l}\text { Runners } \\
\text { runners } \\
\text { runner }\end{array}$ & 14 & 5 & 6 \\
\hline
\end{tabular}

of those that responded, 74 per cent of the runners and 68 per cent of the nonmunners belleved that a preplacement visit did help them adjust to their new placement or would have helped them adjust if they had done so. Runners' and nonrunners' responses are nearly ldentical and no significant differences are noted for the two groups. However, a majority of the subjects affirmed the usefulness of a preplacement visit.

Table 5 presents findings for the varlable of whether subjects recelved preplacement counseling. Elghty per cent of the nonrunners and 61 per cent of the munners had recelved counseling prior to placement. A difference between sample proportions was computed from this data and a $z$ score of 1.461 was obtained. This is smaller than the critical 
value of 1.96 and this result is not significant at the .05 level of signiflcance. Preplacement counseling does not differentiate runners from nonrunners in this sample.

TABLE 5

PREPLACEMENT COUNSELING

Number of Responses Per Category

\begin{tabular}{lccc}
\hline & Yes & No & No Response \\
\hline $\begin{array}{l}\text { Runners } \\
\begin{array}{l}\text { Non- } \\
\text { runners }\end{array}\end{array}$ & 14 & 9 & 2 \\
\hline
\end{tabular}

Summary. No significant differences were noted between runners and nonmunners for the hypothes1s, nor in regard to questions seen as closely related. Areas where differences were expected but not noted included the amount of cholce subjects had in being placed, month of placement, what subjects had heard about the placement and expected it to be like, how near the experience f1t subjects' expectations, the amount and type of preplacement counseling, and whether a preplacement visit had been made. The data does not support the expectation that any of these variables have an effect on runaway behavior. 
In combining the runners and nonrunners, it is interesting to note that in the majority of cases the placement was not like the expectations and the subjects believed a preplacement visit would have helped them adjust to their new placement. The majority of runners and nonrunners comblned did recelve preplacement counseling; however, we did not ask them to specify whether the counseling was associated with this present placement.

A further purpose of this study was to explore input from varlous agencles regarding variables considered relevant to running away. Many of the questions included in the questionnalre were not directly related to the main hypothesis, but had been suggested by various agencies as possibly differentiating a runner from a nonrunner. The findIngs for these variables will be reported on a question-byquestion basis.

Demographically the runners were surprisingly similar to the nonrunners. The mean age for each group was slightly under fourteen. Christie was the only agency in which the runners differed in age from the nonrunners. The Christie nonrunners were on the average one year younger. This cannot be considered a significant overall difference. Table 6 represents this data. 
TABLE 6

MEAN AGE IN YEARS ACCORDING

TO AGENCY

\begin{tabular}{lll}
\hline Agency & Runner & Nonrunner \\
\hline Loulse & 14.70 & 15.00 \\
V1lia & 14.00 & 14.00 \\
Christie & 13.30 & 12.10 \\
St. Mary's & 13.00 & 13.00 \\
Ch1ldren's Farm & 14.40 & 14.80 \\
Cathol1c Charities & 14.50 & 13.50 \\
\hline Mean of Total & 13.97 & 13.74 \\
\hline
\end{tabular}

Our samples were not chosen to equalize a male-female ratio. Each category contained elghteen females and seven males. Hence, there was no difference in our sample for this varlable. The male-female breakdown for each agency is shown in Table 7. (See page 43.)

The racial makeup of the two groups was nearly identical. The muner category contained twenty-three Whites and two Indians. The nonrunner category contained twentyfour Whites and one Black. 
TABLE 7

MALES AND FEMALES IN SAMPLE

ACCORDING TO AGENCY

Number in Each Category

\begin{tabular}{lcccc}
\hline \multirow{2}{*}{ Agency } & \multicolumn{2}{c}{ Runners } & \multicolumn{2}{c}{ Nonrunners } \\
\hline Loulse & 0 & 6 & 0 & 7 \\
Villa & 0 & 1 & 0 & 1 \\
Christie & 0 & 9 & 0 & 8 \\
St. Mary's & 2 & 0 & 2 & 0 \\
Ch1ldren's Farm & 5 & 0 & 5 & 0 \\
Catholic Charlties & 0 & 2 & 0 & 2 \\
\hline Totals & 7 & 18 & 7 & 18 \\
& & & & \\
\hline
\end{tabular}

Simliarly the helghts and welghts of the two groups showed minimal difference. The mean weight for the runners was 123 pounds and for the nonmunners, 127 pounds. The mean helght for the runners was sixty-four inches and for the nonrunners; sixty-five inches. Table 8 displays this information. 
TABLE 8

MEAN HEIGHTS AND WEIGHTS

ACCORDING TO AGENCY

\begin{tabular}{|c|c|c|c|c|}
\hline \multirow[b]{2}{*}{ Agency } & \multicolumn{2}{|c|}{ Height in Inches } & \multicolumn{2}{|c|}{ Welght in Pounds } \\
\hline & Runners & Nonmunners & Runners & Nonrunners \\
\hline Louise & 64.07 & 65.58 & 128.50 & 122.57 \\
\hline Villa & 66.00 & 67.00 & 140.00 & 149.00 \\
\hline Christie & 62.75 & 62.75 & 102.81 & 119.63 \\
\hline St. Mary's & 61.50 & 63.50 & 118.50 & 113.50 \\
\hline $\begin{array}{l}\text { Children's } \\
\text { Farm }\end{array}$ & 65.20 & 67.40 & 122.00 & 103.67 \\
\hline $\begin{array}{l}\text { Catholic } \\
\text { Charitles }\end{array}$ & 65.00 & 63.75 & 127.50 & 152.50 \\
\hline $\begin{array}{l}\text { Mean of } \\
\text { Totals }\end{array}$ & 64.99 & 64.08 & 123.21 & 126.81 \\
\hline
\end{tabular}

Place of residence was considered as a factor influencing runaways. Table 9 summarizes this data. Data for Children's Farm Home is included in this table, but is not included in determining significance because this agency is located outside the Portland area. Excluding Children's Farm Home, 65 per cent of the nonrunners and 30 per cent of the runners lived inside the Portland metropolitan area. This data is presented in Table 9 according to agency. 
TABLE 9

PLACE OF RESIDENCE ACCORDING

TO AGENCY

Number of Responses Per Category

\begin{tabular}{lcccc}
\hline & \multicolumn{2}{c}{ Nonrunners } & \multicolumn{2}{c}{ Runners } \\
Agency & Portland & Outside & Portiand & Outside \\
\hline Loulse & 4 & 3 & 1 & 6 \\
V11la & 0 & 1 & 0 & 1 \\
Christie & 6 & 2 & 3 & 5 \\
St. Mary's & 1 & 1 & 1 & 1 \\
Ch1ldren's Farm & 1 & 4 & 1 & 4 \\
Catholic Char1ties & 2 & 0 & 1 & 1 \\
\hline Totals & 14 & 11 & 7 & 18 \\
\hline Totals excluding & 13 & 7 & 6 & 14 \\
Children's Farm & 13 & & & \\
\hline
\end{tabular}

The difference between two sample proportions was computed and a $z$ score of 3.134 was obtained. Since $z$ was larger than 1.96, the probability that a result this unusual would happen by chance is less than .05. Hence, a signif1cant difference 18 noted for this variable and place of resldence is a factor affecting munaway behavior. Subjects 
are more likely to run if they live outside the Portland metropolitan area where their placement is located.

School achievement and attendance were studied. Table 10 summarizes the data for the subjects' evaluation of their school achievement.

TABLE 10

SCHOOL ACHIEVEMENT

Number of Responses Per Category

\begin{tabular}{lcccccc}
\hline & $\begin{array}{l}\text { Very } \\
\text { Poor }\end{array}$ & Poor & Average & Good & $\begin{array}{l}\text { Very } \\
\text { Good }\end{array}$ \\
\hline \multirow{2}{*}{ Runners } & 0 & 4 & 12 & 6 & 1 \\
Nonmunners & 0 & 2 & 14 & 4 & 5 \\
\hline
\end{tabular}

For statistical purposes the data was grouped in the following way:

$$
\text { Poor } \rightarrow \text { Average Good } \rightarrow \text { Very Good }
$$

Runners

Nonrunners
12

16 
A chi-square value of .0104 was calculated with one degree of freedom and a total $N$ of 44 . This is not significant at .05 level of signiflcance.

Table 11 summarizes the data for subjects' reports of school attendance.

TABLE 11

SCHOOL ATTENDANCE

Number of Responses Per Category

\begin{tabular}{|c|c|c|c|c|}
\hline $\begin{array}{l}\text { Drop- } \\
\text { out }\end{array}$ & $\begin{array}{l}\text { Skip } \\
\text { FrequentIy }\end{array}$ & $\begin{array}{l}\text { Skip } \\
\text { Occasionally }\end{array}$ & $\begin{array}{l}\text { Always } \\
\text { Attend }\end{array}$ & $\begin{array}{l}\text { No } \\
\text { Response }\end{array}$ \\
\hline
\end{tabular}

Runner 0

11

10

1

Non-

runner 1

110

13

0

The two groups are similar concerning this variable also. Therefore, for this population there is no assoclation between school achlevement, school attendance and runaway behavior.

The marital status of each group's parents showed no signiflcant variation. Fifty-six per cent of the runners' parents were divorced versus 64 per cent of the nonrunners' parents. Twenty-four per cent of the runners' parents were 
married versus 20 per cent of the nonrunners' parents.

Twelve per cent of the muners' parents separated versus 8 per cent of the nonmunners' parents. Four per cent of the parents were widowed in each category. Table 12 summarizes this data.

TABLE 12

MARITAL STATUS OF PARENTS

Number of Responses Per Category

\begin{tabular}{lcccccc}
\hline & Married & $\begin{array}{l}\text { Sep- } \\
\text { arated }\end{array}$ & Divorced & $\begin{array}{l}\text { Wid- } \\
\text { owed }\end{array}$ & $\begin{array}{l}\text { Never } \\
\text { Married }\end{array}$ & $\begin{array}{l}\text { No } \\
\text { Response }\end{array}$ \\
\hline Runners & 6 & 3 & 14 & 1 & 0 & 1 \\
$\begin{array}{l}\text { Non- } \\
\text { runners }\end{array}$ & 5 & 2 & 16 & 1 & 1 & 0 \\
\hline
\end{tabular}

The munners' parents had been divorced an average of eight years while. the nonrunners' parents had been divorced an average of 6.4 years. A t test was calculated to determine if this difference was significant. A $t$ value of 1.696 was obtained with thirteen degrees of freedom. This is below the critical value of 2.16 that would be needed for significance at the .05 level. Therefore, length of time parents have been divorced does not appear to be associated with runaway behavior. 
Adoption was another variable studied. Sixteen per cent of the runners and 4 per cent of the nonrunners had been adopted. Table 13 summarizes this data.

TABLE 13

ADOPTION

Number of Responses Per Category

\begin{tabular}{lccc}
\hline & Yes & No & No Response \\
\hline \multirow{2}{*}{ Runners } & 4 & 20 & 1 \\
Nonrunners & 1 & 24 & 0 \\
\hline
\end{tabular}

The difference between two sample proportions was calculated to determine if this variable measured a significant difference. A $z$ score of .358 was obtained. Since $z$ was smaller than 1.96, this indicates that adoption does not appear to be a significant difference between munners and nonmunners in the current study.

Table 14 summarizes the data concerning subjects' previous placements. 
TABLE 14

MEAN NUMBER OF PLACEMENTS

PER AGENCY

Louise Villa Christie Mary's $\begin{array}{lll}\text { Chil- } & \text { Cath- } \\ \text { dren's } & \text { olic } \\ \text { Charlties }\end{array}$

\begin{tabular}{lllllll} 
Runners & 1.57 & 2 & 1 & .5 & 1.4 & 1.5 \\
$\begin{array}{l}\text { Non } \\
\text { runners }\end{array}$ & 2.14 & 1 & .75 & 0 & 1.4 & 4 \\
\hline
\end{tabular}

The average number of previous placements for runners was 1.33 and for nonmunners was 1.55. A $t$ score of -.810 was calculated from this data. At ten degrees of freedom, 2.23 is the critical value indicating there is no significance between previous placements and runaway behavior at .05 level of significance.

Table 15 summarizes the data concerning total time out of the home subjects had spent in placements. (See page 51.)

Runners spent an average of 26.39 weeks in other placements that included juvenile detention centers, foster homes, group homes, and homes of relatives. Nonrunners spent an average of 64.46 weeks in other placements. A t 
score of 1.97 was calculated. With ten degrees of freedom, 2.23 is the critical value. This data shows no significance between groups for the variable of time spent in other placements at the .05 level of significance.

TABLE 15

AVERAGE NUMBER OF WEEKS SPENT IN

PLACEMENTS OTHER THAN HOME

\begin{tabular}{lcccccc}
\hline & Louise & Villa & Christie & $\begin{array}{l}\text { St. } \\
\text { Mary's }\end{array}$ & $\begin{array}{l}\text { Chil- } \\
\text { dren's } \\
\text { Farm }\end{array}$ & $\begin{array}{l}\text { Cath- } \\
\text { olic } \\
\text { Char1ties }\end{array}$ \\
\hline $\begin{array}{l}\text { Runners } \\
\begin{array}{l}\text { Non- } \\
\text { runners }\end{array}\end{array}$ & 22.28 & 3 & 42.28 & 8 & 50.80 & 32 \\
\hline
\end{tabular}

No significant difference between the two groups was noted from the question of who accompanied them when they were first placed in their respective agencles. Fifty-six per cent of the runners were accompanied by their caseworkers versus 64 per cent of the nonrunners. Twenty per cent of the runners and 24 per cent of the nonrunners were accompanied by a caseworker and parents. Sixteen per cent of the runners were accompanied by parents only, versus 8 per cent of the nonrunners. Table 16 presents this data. 
TABLE 16

WHO ACCOMPANIED SUBJECTS TO PLACEMENT

Number of Responses Per Category

\begin{tabular}{lcccc}
\hline & Caseworker & $\begin{array}{l}\text { Caseworker } \\
\text { \& Parents }\end{array}$ & Parents & Other \\
\hline $\begin{array}{l}\text { Runners } \\
\text { Non- } \\
\text { runners }\end{array}$ & 14 & 5 & 4 & 2 \\
& 16 & 6 & 2 & 1 \\
\hline
\end{tabular}

A ch1-square was used to test the data regarding family's attitude toward placement. For statistical purposes the data was grouped as shown in Table 17.

TABLE 17

FAMILY'S ATTITUDE TOWARD PLACEMENT.

Number of Responses Per Category

$$
\text { Very Poor } \rightarrow \text { OK } \quad \text { Good } \rightarrow \text { Very Good }
$$

Runners

14

7

Non-

runners

13

10 
A chi-square value of .145 was obtained with one degree of freedom and a total $\mathrm{N}$ of 44 . This is below the critical value of 3.84 and is not significant at the .05 level of significance. Therefore, in this study family attitude toward the placement is not assoclated with runaway behav1or.

Table 18 summarizes the responses of how subjects felt about the1r placement. Th1s data has been grouped for stat1st1cal purposes.

TABLE 18

HOW SUBJECTS FELT ABOUT PLACEMENT

Number of Responses Per Category.

Very Bad $\rightarrow$ OK $\quad$ Good $\rightarrow$ Very Good

$\begin{array}{llr}\text { Runners } & 17 & 6 \\ \text { Nonrunners } & 21 & 4\end{array}$

A chl-square value of .254 was calculated with one degree of freedom and a total $N$ of 48 . This is below the critical value of 3.84 and is not significant at the .05 level of signiflcance. Subjects' feelings regarding their placement is not a differentiating factor in this study: 
Table 19 summarizes the data regarding who subjects talked with first when arriving at thelr placement.

TABLE 19

WHO SUBJECTS TALKED WITH FIRST

Number of Responses Per Category

Staff Staff \& KIds KIds No Response

\begin{tabular}{lcccc}
\hline & 18 & 1 & 4 & 1 \\
Runners & 18 & 1 & 6 & 0 \\
Nonrunners & 18 & $\vdots$ & & \\
\hline
\end{tabular}

These responses are nearly 1dentical and no significant difference was ellcited from this variable.

Subjects were also questioned as to how welcome the person they first spoke with made them feel. Table 20 summarizes this data.

TABLE 20

HOW WELCOME SUBJECTS FELT

Number of Responses Per Category

\begin{tabular}{lcccccc}
\hline & $\begin{array}{l}\text { Not. } \\
\text { At All }\end{array}$ & $\begin{array}{l}\text { Very } \\
\text { Little }\end{array}$ & Some & A. Lot & Very Much & $\begin{array}{l}\text { No } \\
\text { Response }\end{array}$ \\
\hline \multirow{2}{*}{$\begin{array}{l}\text { Runners } \\
\text { Nonmunners }\end{array}$} & 1 & 1 & 10 & 7 & 4 & 2 \\
\hline
\end{tabular}


Again, the two groups are so similar that no significant difference is noted.

The existence of a buddy program (or big brother or big sister program) in the agencles was a variable questloned. The results are summarized in Table 21 .

\section{TABLE 21}

EXISTENCE OF A BUDDY PROGRAM

Number of Responses Per Category

\begin{tabular}{lccc}
\hline & Yes & No & No Response \\
\hline Runners & 8 & 15 & 2 \\
Nonrunners & 9 & 10 & 6 \\
\hline
\end{tabular}

A chi-square value of .123 was computed from this data with one degree of freedom and a total $\mathrm{N}$ of 42 . Th1s is below the critical value of 3.84 and is not significant at the .05 level of significance. Hence, a buddy system is not a significant differentiating factor between the two groups.

Table 22 summarizes the data of how of ten caseworkers have visited subjects since their placement. 
TABLE 22

HOW OFTEN CASEWORKERS HAVE

VISITED SUBJECTS

Number of Responses Per Category

\begin{tabular}{lcccccc}
\hline & $\begin{array}{l}\text { Not } \\
\text { At All }\end{array}$ & Rarely & Some & often & $\begin{array}{l}\text { Very } \\
\text { Often }\end{array}$ & $\begin{array}{l}\text { No } \\
\text { Response }\end{array}$ \\
$\begin{array}{l}\text { Runners } \\
\begin{array}{l}\text { Non- } \\
\text { runners }\end{array}\end{array}$ & 1 & 10 & 10 & 2 & 0 & 2 \\
\hline
\end{tabular}

Combining categories for statistical purposes, the following results were obtalned:

\begin{tabular}{lcc}
\hline Not At All $\rightarrow$ Rarely & Some $\rightarrow$ Very Often \\
\hline Runners & 11 & 12 \\
Nonmunners & 12 & 11 \\
\hline
\end{tabular}

These categories are too similar to contain a significant difference. Hence, the groups are not significantly different on the variable of how often their caseworkers have visited them.

Table 23. summarizes the data of how often subjects would have liked their caseworkers to visit. 
TABLE 23

HOW OFTEN SUBJECTS WOULD LIKE

CASEWORKERS TO VISIT

Number of Responses Per Category

\begin{tabular}{lcccccc}
\hline & $\begin{array}{l}\text { Not } \\
\text { At All }\end{array}$ & Rarely & Some & often & $\begin{array}{l}\text { Very } \\
\text { Often }\end{array}$ & $\begin{array}{l}\text { No } \\
\text { Response }\end{array}$ \\
\hline $\begin{array}{l}\text { Runners } \\
\begin{array}{c}\text { Non- } \\
\text { runners }\end{array}\end{array}$ & 3 & 4 & 6 & 9 & 1 & 2 \\
\hline
\end{tabular}

Combining categories, the following results were obtained:

\begin{tabular}{lcc}
\hline & Not At All $\rightarrow$ Rarely & Some $\rightarrow$ Very often \\
\hline Runners & 7 & 15 \\
Nonmunners & 11 & 12 \\
\hline
\end{tabular}

A chi-square value of .049 was computed from this data with one degree of freedom and a total $N$ of 45 . This is below the critical value of 3.84 and is not significant at the .05 level of significance. Therefore, the number of caseworker visits desired is not a significant difference between the runners and nonrunners. 
Subjects were questloned as to whether they had run from their own homes. Table 24 summarized this data.

TABLE 24

SUBJECTS RUNS FROM THEIR HOMES

Number of Responses Per Category

\begin{tabular}{lccc}
\hline & Yes & No & No Response \\
\hline Runners & 16 & 7 & 2 \\
Nonmunners & 13 & 11 & 1 \\
\hline
\end{tabular}

From this data, a ch1-square value of .617 was calculated with one degree of freedom and a total $\mathrm{N}$ of 47 . This is below the critical value of 3.84 and is not significant at the .05 level of significance. Runs from subjects' own homes is not a significant differentiating factor between the two groups.

Simliarly, no significant difference was noted for the two groups on the variable of whether other members of the subjects' familles had run. Table 25 summarizes this data. 
TABLE 25

OTHER FAMILY MEMBER RUNAWAYS

Number of Responses Per Category

\begin{tabular}{lcccc}
\hline & Yes & No & No Response \\
\hline Runners & 10 & 12 & $\ddots$ & 3 \\
Nonrunners & 10 & 15 & & 0 \\
\hline
\end{tabular}

Summary

Many variables were considered as possible differences between runners and nonrunners. Demographic data, school achlevement and attendance, marital status of parents, time spent in other placements, subjects and subjects' families' attitude toward the placement, who subjects talked with first, the existence of a buddy program, adoption, caseworker visits, muns from own homes and muns by other family members, were variables studied. of these, only place of residence elicited a slgnificant difference between the two groups. Subjects are more likely to mun if they reside outside the Portland metropolitan area. These results do not apply to Children's Farm Home which is outside the geographical area and was not considered in this question. In order to complle a profile of a typical run, runners were asked a varlety of open ended questions. (See 
Questionnaire in Appendix B, Part I, page 5, questions 31 through 38.) This data is not stat1stically significant but does present a description of the most commonly described events, feelings and behaviors that were associated with running away.

Runners in this sample typically left their agency in the late afternoon or evening (with the exception of one subject who always ran in the morning because the night time was too scary). The common mode of transportation is walkIng to the nearest place to be plcked up as a hitchhiker.

Although a few subjects ran due to boredom, the majorIty were involved in a hassle with a staff person, wanted to support a friend, were uptight with a family member, were anticlpating detention, or were anxious regarding an upcoming home visit.

Most subjects reported being angry and upset at the time they ran. There were some reports of feeling sadness, shame, and fear. Although a few subjects stated they felt glad and happy to be getting away, hurt and anger were the prevaliling moods.

Almost overwhelmingly, these runs were not planned but were Impulsive decisions. Only four runners had planned their actions in advance and, of these, one had been planned only a half-hour before. 
Subjects typically ran with a friend or two from their placement. Those who ran alone almost always ran to their homes or the home of a friend. Most subjects ran to a friend's home, or often to the home of a friend's friend. A. few ran to their own homes. Only two respondents went to places where they didn't have an acquaintance--one to a motel and another to a boat on which to sleep.

Part II, pages 1-4, of the questionnalre were made up of questions presented by residents of Villa St. Rose. Runners and nonrunners were asked how important they considered each of twnety-two variables to be in running away. A factor analysis was calculated for this data, combining both samples. Runners and nonrunners were combined due to the small sample. A transgeneration was first performed, inserting means in categorles where no response had been given. The total $\mathrm{N}$ was fifty and the number of variables twenty-two. Eight factors were obtained from this procedure. The eight factors will be described separately with the most highly correlated variables described.

In most cases a cutoff value of .50 was utilized in including variables in the factor. Some items with a correlation close to this value were included. This part of the questionnalre was headed by the question, "In your opinIon, how much importance does this have in running away?" 
The twenty-two varlables followed and subjects were asked to check one of flve possible answers--not at all, very little, some, a lot, or very much.

Factor 1 was named Conflictual Relationships With Staff. The variables and their correlation coefficient are Iisted below:

$\begin{array}{ll}\text { Statement } & \begin{array}{l}\text { Correlat } \\ \text { Coefflct }\end{array} \\ \text { Staff not taking enough time with kids. } & .798 \\ \text { Staff not trusting klds. } & .801 \\ \text { Staff not being honest with kids. } & .578 \\ \text { Not getting help with problems. } & .705 \\ \text { Feeling depressed. } & .483\end{array}$

This factor may relate to Konopka's criticisms of workers in institutions. See Review of the Literature, Chapter II, page 14, for a more complete description of Konopka's 1deas. She sees workers as coming from sheltered backgrounds with unrealistic idealism and as becoming disillusioned and hardened when dealing with the realities of institution work. When workers are unprepared for the hostility and resistance residents bring, they retallate with discouragement and power trips. This in turn increases anger, frustration and the urge to flee. Factor 1 includes a dissatisfaction with the amount of attention and type of treatment subjects percelve they are recelving, as well as the quality of relationships subjects percelve as being offered. 
Factor 2 was named Impulse Control. These varlables and their correlation coefficients are listed below:

Statement $\quad \begin{aligned} & \text { Correlation } \\ & \text { Coefficient }\end{aligned}$

When I am tempted to get loaded on drugs.

When I feel a need to have sex.

When I feel depressed.

When I think I'll get to go home.

When I have hassles with parents during home visits.

.637

.594

.509

.802

.498

This factor relates to Leventhal's idea of inner control that runners often lack (See Chapter II, Review of the Ilterature, page 10). Th1s factor appears to define running away as a discharge type of behavior--an attempt to deal with uncomfortable feelings and conflicts. Lack of control over Impulses was a dominant theme pursued during group therapy for munners in the Leventhal study.

Factor 3 was named Environmental Stress and was made up of the following variables:

\begin{tabular}{ll} 
Statement & $\begin{array}{l}\text { Correlation } \\
\text { Coefficient }\end{array}$ \\
\hline
\end{tabular}

When I have an upsetting counselIng session. and not caring. When I am tired of being told what to do.

.803

.654

.456

Dach of the variables describe stress in the living situation and conflicted relationships within the living group. 
This is another commonly described factor in the literature related to runaways. Noncommunication which frustrates basic needs of affection and acceptance, and conflict or confrontation in the living group, of ten leads to a flight reaction.

"Good" Parent Role Model was the name assigned to Factor 4 which was made up of the following varlables:

Statement $\quad \begin{aligned} & \text { Correlation } \\ & \text { Coefficient }\end{aligned}$

When I don't have close relationships with staff members.

When the staff doesn't set limits for me.

When the staff is not honest with me.

620

The variables in this factor are interpreted as longing for an idealized parent figure--who is willing to be close, who sets limits (surely acceptable, fair limits), and who will be involved in an open, honest relationship with the youth. Affection and acceptance were key areas of conflict that led up to runaway behavior in the Blood and D'Angelo study (see Review of the Literature, Chapter II, page 11).

Factor 5 was named Isolation and is made up of the following variables: 
Statement

When I lose contact with the staff.

When I am uptight or scared.

When someone gets too close to my problems.
Correlation

Coefficlent

.849

.521

.732

These questions have in common a feeling of isolation and vulnerability. The subjects in this sample consider these stressful feelings as a precipitator of runaway behavior. Blood and D'Angelo developed a hierarchy of adolescents' needs. One is a need for total acceptance--to be understood, to communicate with other people, and to express inner thoughts and feelings without loss of status. This factor appears to reflect slmilar ideas to Blood and D'Angelo.

Factor 6 was named D1sturbed Peer Relations. The varlables are listed below:

Statement $\quad \begin{aligned} & \text { Correlation } \\ & \text { Coefflcient }\end{aligned}$

When I have hassles with other kids. $\quad .734$ When I lose contact with friends. $\quad .809$

Both these variables indicate that problems and isolation from the peer group are considered an influence in runaway behavior. The literature and findings in other parts of this study indicate conflict with family, staff, or other 
authority flgures are a factor in muning away. These findings indicate disturbed peer relationships as another factor. Authority was the name given to Factor 7 which is made up of the following variables:

Statement

When the staff looks for problems that really don't exist. When I am having problems at school.
Correlation

Coefficient

.604

.852

This information colncides with much of the literature as well as other findings in this study. Pressure and conflict with authority figures is a commonly reported precipitation of runaway behavior.

Factor 8 was titled Helplessness. It consists of the following factors:

Statement

Correlation Coefflcient

When I am tired of being told what to do.

When I feel locked in.

This information is again related to Leventhai's findings in which helplessness and a feeling of lack of control over external circumstances is a prelude to running away.

Part II, page 5 of the questionnaire consisted of a number of possibilities of when youths are most likely to 
run and where they are most likely to run to. Subjects were asked to choose from a range of responses from "disagree strongly" to "agree very much." These responses were rated from one to five and a mean score was calculated for each question and for each group. Table 26 displays this information. (See page 68.)

Several general observations can be gleaned from this data. Both munners and nonrunners have a high degree of agreement that youths are most likely to run during the summer. Both groups disagree somewhat that just before release time is a likely time to run. Running to a friend's house recelved strong agreement for each group. This agrees with findings from the open ended questions that runners were asked regarding their munaway behavior. This information also indicated that youths are most likely to run to a friend's house.

Runners generally scored from one-half to one point lower than nonrunners. One possible interpretation for this is that runners have stronger opinions regarding the details of runaway behavior.

Part II, pages 7 and 8 of the questionnatre were made up of thirteen statements that subjects were asked to agree with from a range of not at all to very much. A factor analysis was calculated with this data. Runners and nonrunners were combined for statistical purposes. A transgeneration was 
TABLE 26

MEAN RESPONSES OF QUESTIONS AS TO WHEN SUBJECTS

ARE MOST LIKELY TO RUN AND WHERE THEY

ARE MOST LIKELY TO RUN TO

KIds are most $11 \mathrm{kely}$ to run during:
Runners

Non-

Runners

Spring

2. 3

$3 \cdot 3$

Summer

4.1

4.2

Winter

2.8

2.8

Fall

2.6

3.1

Breaks

(a) morning, (b) lunch, (c) evening $3: 3 \quad 3.2$

Group outings

$2 \cdot 9$

3.2

Home visits

2.4

3.3

During outside employment

2.0

2.8

Just before release time

1.8

2.0

At holiday. time

2.4

3.2

Kids mun to:

Home

3.1

3.2

Seattle

1.9

2.8

California

$2 \cdot 3$

2.8

Parks

2.1

3.1

Communes

1.9

3.1

Friends

4.8 
first performed, inserting means where no response had been given. The total $\mathrm{N}$ was fifty and the number of variables was thirteen. Five factors were obtalned from this procedure. These factors will be described separately with the variables most highly correlated described. In most cases the cutoff value was .50 for including variables in the factor. Some items with a slightly smaller correlation were included.

Factor 1 was named Support Group and included the following varlables:

Statement

I like getting to know the adults here. It helps to talk about my feelings in group. The group outings we have are fun. It's helpful to have someone around to talk with.
Correlation Coefficient

.775

.671

.825

These variables indicate acceptance of values and behaviors that are commonly considered part of any effective residential treatment program. An amenability to treatment and ability to form close, meaningful relationships are also indicated by these statements.

Factor 2 was named Family Dissension, with the following varlables being highly correlated: 


Statement $\quad \begin{gathered}\text { Correlation } \\ \text { Coefficient }\end{gathered}$

We had lots of fights at my house.

My mother hit me a lot.

I often wanted to run away.

.536

.898

.547

This factor relates to findings from other studies that family conflict, and particularly physical abuse, is higher among runaways. Running away can be an avoldance of an intolerable home situation. Shellow indicated that family conflict has a direct bearing on munaway behavior.

Factor 3 was named Family Feeling Dysfunction. The following variables were included:

$\begin{array}{lr}\text { Statement } & \begin{array}{l}\text { Correlat1 } \\ \text { Coefflc1 }\end{array} \\ \text { My father loved me. } & -.753 \\ \text { I had fun with my brothers and } & -.812 \\ \text { sisters. } & -.654 \\ \text { I like doing things on schedule. } & \end{array}$

This factor relates to Factor 2 and findings in the i1terature. Runaways come from homes with a high amount of conflict. Further, some researchers believe the nature of this conflict to be major conflict over minor issues. This permits the displacement of intense anger to areas where it may be handled with less risk of totally disrupting fraglle famliy relationships (Blood and $D^{\prime}$ Angelo). Hence the factors relating to lack of parental love and lack of positive ex- 
perlences with slblings indicate serlous dysfunction in the family and this may be handled by conflict.

Parental Acceptance was the name given Factor 4.

\begin{tabular}{lr} 
Statement & $\begin{array}{r}\text { Correlat } \\
\text { Coeffic }\end{array}$ \\
\hline I considered my parents strict. & -.720 \\
My parents were very understand- & .807 \\
Ing of me. & -.413
\end{tabular}

In this sample, subjects considered parental understanding as being nearly opposite to parental strictness. Subjects who describe their parents as understanding, do not consider them to be strict and did not often want to min away. Th1s again relates to findings in the literature which indicate parental acceptance to be a major need of adolescents.

Factor 5 was named Parental Protection, and "There was usually someone there when I came home," was the only statement highly correlated for this factor with a value of .884 . 
CHAPTER VI

SUMMARY OF RESULTS

Our goal was to obtain reliable data as to whether preplacement counseling and visitation made a significant difference in runaway behavior of youth in residential facilities. The results of the questions relating to the hypothesis showed no statistically significant difference between runners and nonmunners. Other questions were not directly related to the hypothesis, but had been suggested by various agencies as possibly differentiating a runner from a nonrunner. Of these, the only significant variable was place of residence. Subjects were more likely to run if their residence was outslde the Portland metropolitan area. A profile of the typlcal run was complled from questions asked of the munner. Th1s is not stat1st1cally significant data, but it does describe the most common events, feelings and behavior that were associated with running away .

A total of thirteen factors were obtained from two separate factor analyses. Runners and nonrunners were combined to form one sample. The following factors with their varlables were obtalned from the first factor analysis. 
Factor 1. Conflictual Relationships with Staff

Staff not taking enough time with kids.

Staff not trusting kids.

Staff not being honest with kids.

Not getting help with problems.

Feeling depressed.

Factor 2. Impulse Control

When I am tempted to get loaded on drugs.

When I feel a need to have sex.

When I feel depressed.

When I think I'll get to go home.

When I have hassles with parents during home visits.

Factor 3. Environmental Stress

When I have an upsetting counseling session.

When the living group is uptight and not caring.

When I am tired of being told what to do.

Factor 4. "Good" Parent Role Mode1

When I don't have close relationships with staff members.

When the staff doesn't set limits for me.

When the staff is not honest with me.

Pactor 5. Isolation

When I lose contact with the staff.

When I am uptight or scared.

When someone gets too close to my problems.

Factor 6. D1sturbed Peer Relations

When I have hassles with other kids.

When I lose contact with friends. 
Factor 7. Authority

When the staff looks for problems that really don't exist.

When I am having problems at school.

Factor 8. Helplessness

When I am tired of being told what to do. When I feel locked in.

The factors obtained from the second factor analysis are as follows:

Factor 1. Support Group

I like getting to know the adults here.

It helps to talk about my feelings in group.

The group outings we have are fun.

It's helpful to have someone around to talk with.

Factor 2. Family Dissension

We had lots of fights at my house.

My mother hit me a lot.

I of ten wanted to mun away.

Factor 3. Family Feeling Dysfunction

My father didn't love me.

I didn't have fun with my brothers and sisters.

I don't like dolng things on schedule.

Factor 4. Parental Acceptance

I didn't consider my parents strict. My parents were very understanding of me.

I didn't often want to run away. 
Factor 5. Parental Protection

There was usually someone there when I came home.

Subjects were questioned as to when youths are most likely to run and where they are most likely to mun to. Runners and nonrunners had a high degree of agreement that youths are most likely to run during the summer and to run to the home of a friend. Both groups disagree that just before release is a likely time to run.

\section{Summary of Methodology}

The research design proved to be appropriate for the kind of data that we sought to collect and analyze. Both subjective and objective data were collected by using a twopart instrument. Part I was administered as an interview by the research team and Part II was answered directly by the subject.

The instruments were for the most part very adequate for ellciting open responses. However, in Part I the wording in several questions was not specific enough to get at the definitive information that we needed. Part II was most successful in delineating the needs and feelings of the respondents.

of the subjects, the runner group was judged to be fairly representative. However, the matching group of 
nonmunners was too similar in characteristics and experience to make the results signiflcant. We belleve that this was the case because of the fact that the nonrunner sample, though not running in October, 1974, had indeed had a history of running away.

Our procedures were satisfactory in accomplishing the tasks. The only difficulty encountered was that of scheduling interviews that were convenient for all persons involved. The interviewees were, wlth few exceptions, affable, interested and cooperative.

\section{Implications and Recommendations}

In the opinion of the authors, this research study might have proven more significant if the data had been collected from a selected control group that had been specifically involved in preplacement counseling, previsitation and participation in planning for their own treatment plan. (Our question No. 28 did not clearly define whether the preplacement counseling was related to this present placement.) For future research we would suggest that a model program be implemented within one of these agencies. W1thin such a. program we would recommend that the young person have some input into their own treatment plan, as well as counseling and visitation, well before placement. 
Our results indicated that a majority of those questioned felt that they wanted to be involved in their own placement, by visiting and planning. This need not to feel helpless is substantlated throughout the literature. Evaluations of this plan could more accurately be made if such a group could be treated within an agency, while the control remalned untreated in the same agency. This would take care of the varlables between agencles.

Some differential factors that emerged suggest a need for more complete evaluation of individual agencies in view of their different programs and populations. For example, a variable which might be of interest for further research is that associated with the kind of schooling provided. Since school problems, falling and truancy, are thought to be factors preceding runs, these situations are minimized in facilities that have schools in residence. This factor could be separately associated (see Table 5, page 40, and Table 6, page 42 ).

Another factor found to be important by the youths questioned was the location of the placement as related to their homes. The need to maintain contact with friends was noted as being important. Youth who were placed some distance from their homes and friends ran more frequently. It has been suggested to us by one of the particlpating agencles that our instruments would be very useful as 
profective tools in interviewing their own residents. They felt that our questionnaire elicited valuable responses that they would otherwise not have gotten. Following this implication, it would seem fruitful to use such data in making Individualized treatment plans for their residents, as well as being able to avold if possible those anxiety producing stress situations that cause th: young person to mun. 
FOOTNOTES

I"Runaway Children--A Problem for More and More Cities,". U.S. News \& World Report, April 24, 1972, 38-42.

${ }^{2}$ Lawrence S. Bradshaw, et al., "Runaway Youth in Salt Lake County" (unpublished Master's thesis, University of Utah, 1969).

3 James A. H1ldebrand, "Why Runaways Leave Home," Journal of Criminal Law, Criminology and Police Science', Vol. 54 (June, 1963), 211-216.

4

Ivan Nye and James F. Short, Jr., "Scaling Delinquent Behavior," American Soclological Review, June, 1957, pp. 326-331.

5 Robert Shellow, et al., "Suburban Runaways of the $1960^{\prime} \mathrm{s}$, "Monographs of the Soclety for Research in Child Development; XXXII, No. 3, 1967, pp. 1-37.

$6_{\text {Ibid., p. } 19 .}$

Ibid., pp. 36-37.

8 Amos Robey, et al., "The Runaway G1rl: A Reaction to Family Stress," American Journal of Orthopsychiatry, XXIV, No. 4, (July, 1964), pp. 762-767.

${ }^{9}$ Clyde B. Vedder, The Runaway Girl' (Englewood, N.J.: Prentice-Hall, 1958), Chap. IV.

${ }^{10}$ Randall Foster, "Intrapsychic and Environmental Factors in Running Away From Home," American Journal of Orthopsychiatry, XXXIV (Apri1 1, 1962), pp. 486-491.

11 Robey, et al., pp. 765.

12 Fredrick Rosenhe1m, "Techniques of Therapy," American Journal of Orthopsychiatry, $\mathrm{X}$, (1940), pp. 651-665.

${ }^{13}$ Ibid., p. 657 . 
14

Robey, et al., p. 763 .

15 Theodore Leventhal, "Inner Control Deficiencies in Runaway Children," Archives of General Psychiatry, I (August, 1964), pp. 170-176.

16 Ib1d., p. 170 .

17 Linda Blood and Rocco D'Angelo, "A Progress Research Report on Value Issues in Conflict Between Runaways and Their Parents," Journal of Marriage and the Family, Vol. 36, No. 3 (August, 1974), pp. 486-491.

18 Ib1d., p. 487 .

19. Ib1a., p. 490.

${ }^{20}$ David Street, Robert D. Vinter and Charles Perrow, Organization For Treatment (New York: Free Press, 1966).

21

Ib1d., p. 278 .

${ }^{22}$ Lloyd McCorkle, Albert Ellas and F. Lovell Bixby, The Highfields Story (New York: Henry Holt and Company, 1958).

23

Gisela Konopka, The Adolescent Girl in Conflict (Englewood, N.J.: Prentice-Hall, 1966).

24 Institutional Rehabilitation of Delinquent Youth, National Conference of Superintendents of Training Schools (Albany, N.Y.: Delmar Publishers, 1962).

25 Ib1d., pp. $45-49$. 


\section{SELECTED BIBLIOGRAPHY OF \\ PERTINENT LITERATURE}

\section{Books}

Alchorn, August. Wayward Youth. New York: The Viking Press, 1935.

Ambrosino, Lililian. Runaways. Boston: Beacon Press, 1971.

Armstrong, Clariette P. 660 Runaway Boys. Boston: Gorhom Press, 1932.

Bock, Richard and English, Ab1gail. Got Me on the Run. Boston: Beacon Press, 1973.

Dornbusch, Sanford and Schm1d, Calvin. A Primer of Social

Stat1st1cs. New York: McGraw-H11I Book Company, 1955.

Forcese, Dennis and Richer, Stephen. Social Research Methods. Englewood, N.J.: Prentice-Hall, Inc., 1973.

McCorkle, Lloyd; Ellas, Albert; and F. Lovell Bixby. The Highlands Story. New York: Henry Holt, 1958.

Street, David; Vinter, Robert D.; and Perrow; Charles. Organization for Treatment. New York: The Free Press, 1966.

Thom, D. A. Normal Youth and Its Everyday Problems. New York: Appleton, 1933.

Vedder, Clyde. B. The Runaway G1rl. Englewood, N.J.: 'Prent1ce-Hali, 1958.

National Conference of Superintendents of Training Schools and Reformatories. Institutional Rehabilitation of Delinquent Youth. Albany, N.Y.: Delmar Publishers, 1962 . 


\section{Articles and Periodicals}

Balser, B.H. "A Behavior Problem--Runaways." Psychlatric Quarterly, XIII (1939), 539-557.

Blood, Linda and D'Angelo, Rocco. "A Progress Research Report on Value Issues in Conflict Between Runaways and Their Parents." Journal of Marriage and the Family, Vol. 36, No. 3(August, 1974), 486-491.

Foster, Randall M. "Intrapisychic and Environmental Factors in Running Away from Home." American Journal of Orthopsychiatry, XXXIV (Apr11, 1962, 486-491.

Frank, Lawrence K. "Community Planning for Children and Youth." Soc1al Forces, XXIV (May, 1946), 385-388.

H1ldebrand, James A. "Why Runaways Leave Home." Journal of Criminal Law, Criminology and Police Sclence, LIV (June, 1963), 211-216.

Holt, Norman. Escape from Custody, Research Report No. 52, Research Division, California Department of Corrections (May, 1974), 1-63.

Leventha1, Theodore. "Control Problems in Runaway Ch11dren." Archives of General Psychlatry, IX (August, 1963), 122-126.

Leventhal, Theodore. "Inner Control Deficlencies in Runaway Children." Archives of General Psychiatry, IX (August, $1964)$, , $170-176$.

Lowrey, L. G. "Runaways and Nomads." American Journal of Orthop sychiatry, XI (October, 1941), 775-783.

Nye, Ivan F., and Short, James F. "Scaling Delinquent Behavior." American Soclologlcal Revlew, XXII (June, 1957), 326-331.

Outland, G. E. "Determinants Involved in Boy Translency." Journa of Educational Soclology, XI (February, 1938), 360,372 .

Outlan $\mathscr{C}$, G. E. "The Home Situation as a Direct Cause of Boy Transiency." Journal of Juvenile Research, XXII (1938), 33-43. 
Peters, William. "Riddle of Teenage Runaways." Good Housekeeping, CLxVI (June, 1968), 88-89, ff.

Rein, Martin. "The Social Service Crisis." Trans-Action, I (May, 1964), 3-6, ff.

Robey, Amos, et al. "The Runaway Girl: A Reaction to Fam1ly Stress." American Journal of Orthopsychiatry, XXXIV (July, 1964), 762-767.

Robins, Lee N. "Mental Illness and the Runaway: A 30 Year Follow-up study." Human Organization, XVI (Winter, 1958), 11-15.

Robins, Lee N., and O'Neal, Patricia. "The Adult Prognosis for Runaway Children." American Journal of Orthopsychlatry, XXIX (October, 1959), 752-761.

"Runaway Children--A Problem for More and More Cities." U.S. News \& World Report, (April 24, 1972), 38-42.

"Runaway KIds." Life, LXIII (November 3,' 1967), 18-29.

"Runaways: Teenagers Who Run Away to the Hippies." Time. XC (September 15, 1967), 46, ff.

Shellow, Robert, et al. "Suburban Runaways of the 1960's." Monographs of the Soclety for Research in Child Development, XXXII, No. $3(1967), 1-37$.

Stark, Heman G. "Standards for Juventle Halls." Federal Probation, XXIV (March, 1960), 35-41.

Tunley, Roul. "If You're Thinking of Running Away." Seventeen (February, 1968), 138-139, ff.

Wh1tbread, Jane. "Runaways: Greenwich Village. Case Historles." Look, XXXI (July 25, 1967), 26-32.

Wylie, Dorothy C., and Weinreb, J. "The Treatment of a Runaway Adolescent Girl Through the Treatment of the Mother " American Journal of Orthopsychiatry, XXVIII (January, 1958). 


\section{Unpublished Materials}

Bradshaw, Lawrence Stuart, et al. "Runaway Youth in Salt Lake County: A Study of Their Use of Soclal Service Agencies and Community Planning Related to Their Problems." Unpublished Master's Thesis, Graduate School of Soclal Work, University of Utah (1969), $1-96$.

Greer, Susan G.; Hertle1n, Sarah J.; and Regner, Stephen C. "A Study of the Characteristics of Runaways and Their Families in Two Soclal Agencles." Unpublished Master's Practicum, Portland State University School of Soclal Work (1972), 1-40.

Study of Wandering Youth, Council of Planning Affillates, Seattle, washington, 1973. 
APPENDICES 
APPENDIX A

Pretest Interview Questionnalre

1. Age 2. Sex 2. Race

4. Height 5 5. We1ght 6 . Hometown 7. School Achlevement V. good
Average _ Poor
V. poor

8. School Attendance Always Almost Skip Skip Dropfreq. out always Occas.

9. Marital status of parents Married Divorced* Widowed* _ Never married Don't know

* Give number of years ago.

10. Were you adopted?

11. Number of siblings and order

12. Where were your previous placements? (May be more than one) Own family _ Group home __ Fosterhome JDH other

13. Length of time in each

14. What month did you come to this placement?

15. Who came with you when you were placed?

16. What is your family's attltude toward your belng here? V. good V. poor Good $0 . K$. Poor

17. How do you feel about your placement here? V. good Good $0 . K$. Bad $\mathrm{V}$. bad 
18. How much do you think that you were involved in choosing this placement? V. much v. little Not at all A $10 t$ Some

19. What had you heard about this placement and what did you expect it to be like?

20. Was 1t like you had expected?

21. Who did you first meet? Staff, k1ds, who?

22. Did they make you feel welcome?

23. Did you make a pre-placement visit?

24. How often has the caseworker visited you since your placement? V. often often _ Sometimes Rarely Not at alI_

25. Had you recelved counseling before this placement? Probes: Kind, how long, by whom?

For runners:

26. Did you ever mun away from your own home?

27. What was the month, day and hour that you last ran?

28. Had anything special occurred to cause you to run at that time? Explain.

29. What were your feelings at that time? Probes: Angry, sad, trapped, lonely, other? 
30. Were there any consequences for prior runs? Describe.

31. Had you planned this run for some time?

32. Did you run without planning?

33. Did you mun alone? If others, whom?

34. Where did you go?

Probes: Home, boyfriends, girlfriends, other? 


\section{APPENDIX B}

PART I

Final Questlonnalre for Runners And Nonrunners

Sponsoring Agency

Date

Interviewer

$\begin{array}{llll}\text { 1. Age 2. Sex } & 1 . & 2 . \\ \text { 3. Race 4. Helght } & 3 . & 4 . \\ \text { 5. Welght 6. Hometown } & 5 . & 6 .\end{array}$

7. School achievement

7.
poory Poor Ave. Good $\begin{aligned} & \text { Very } \\ & \text { good }\end{aligned}$

8. School attendance

8. $\overline{\text { Drop- Sk1p Skip Always }}$ out freg. occas.

9. Marital status of parents

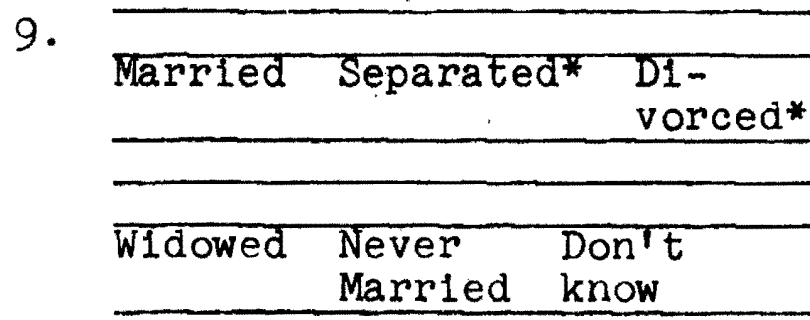

*Number of years ago. 
10. Were you adopted?

10.

Yes No

11. Number of siblings 11 . and order

(circle interviewee)

12. Where were your previous placements and order?

(May be more than one)

12.

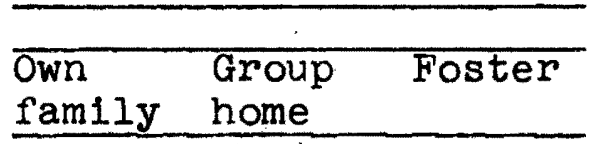

family home

JDH other

13. Length of time in each

13.

Own Group Foster

family home

JDH Other

14. What month did you 14. come to this placement?

15. Who came with you 15. when you were placed?

16. What is your fam$11 y$ 's attitude toward your being here?

16. Very Poor 0.K. Good Very poor Good 
17. How do you feel about your placement here?

18. How much choice do you think you had in being placed here?

19. What had you heard about this placement?

20. What did you expect it to be like?

21. Was it like you had 21. expected?

22. Who do you remember 22. talking to first? Staff, kids, who?

23. How welcome did they make you feel?

23.

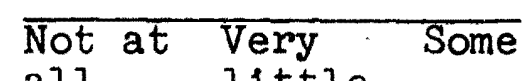

all little

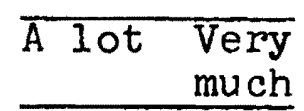

24. Is there a buddy system (big sister or brother) in this agency?

24. 
25. Did you make a

pre-placement

visit?

A." Do you think

this would have

helped?

25.

26. How often has your caseworker visited you since your

placement?

26.

A.

27. How often would

you have liked the caseworker to

visit you?

27.

Not at Rarely Some-

all $\quad$ times

\begin{tabular}{ll}
\hline Often & $\begin{array}{l}\text { Very } \\
\text { Often }\end{array}$ \\
\hline
\end{tabular}

Not at Rarely Some-

all

times

\begin{tabular}{ll}
\hline often & $\begin{array}{l}\text { Very } \\
\text { often }\end{array}$ \\
\hline
\end{tabular}

28. Had you recelved counseling before this placement?

Probes: kind, how long, by whom?

29. Did you ever run

29. away from your own home?

A. When did you

first run?

B. What happened at that time?

28.

A.

B.

30. Have any members of your family run?

30.

$\overline{\text { Yes No }}$ 
31. What was the month, day, and hour that you last ran?

32. How did you leave? Probe: 32.

33. Had anything special occurred to cause you to run at that time? Expiain. 33.

34. What were your feelings at 34 . that time?

Probes: angry, sad, trapped, lonely, etc.

35. Were there any consequences 35. for prior runs? Describe.

\section{.}

36. Had you planned this run? 36.

37. Did you run alone? If others, with whom?

37 .

38. Where did you go?

38. Probes: home, boyfriend, girlfriend, other? 


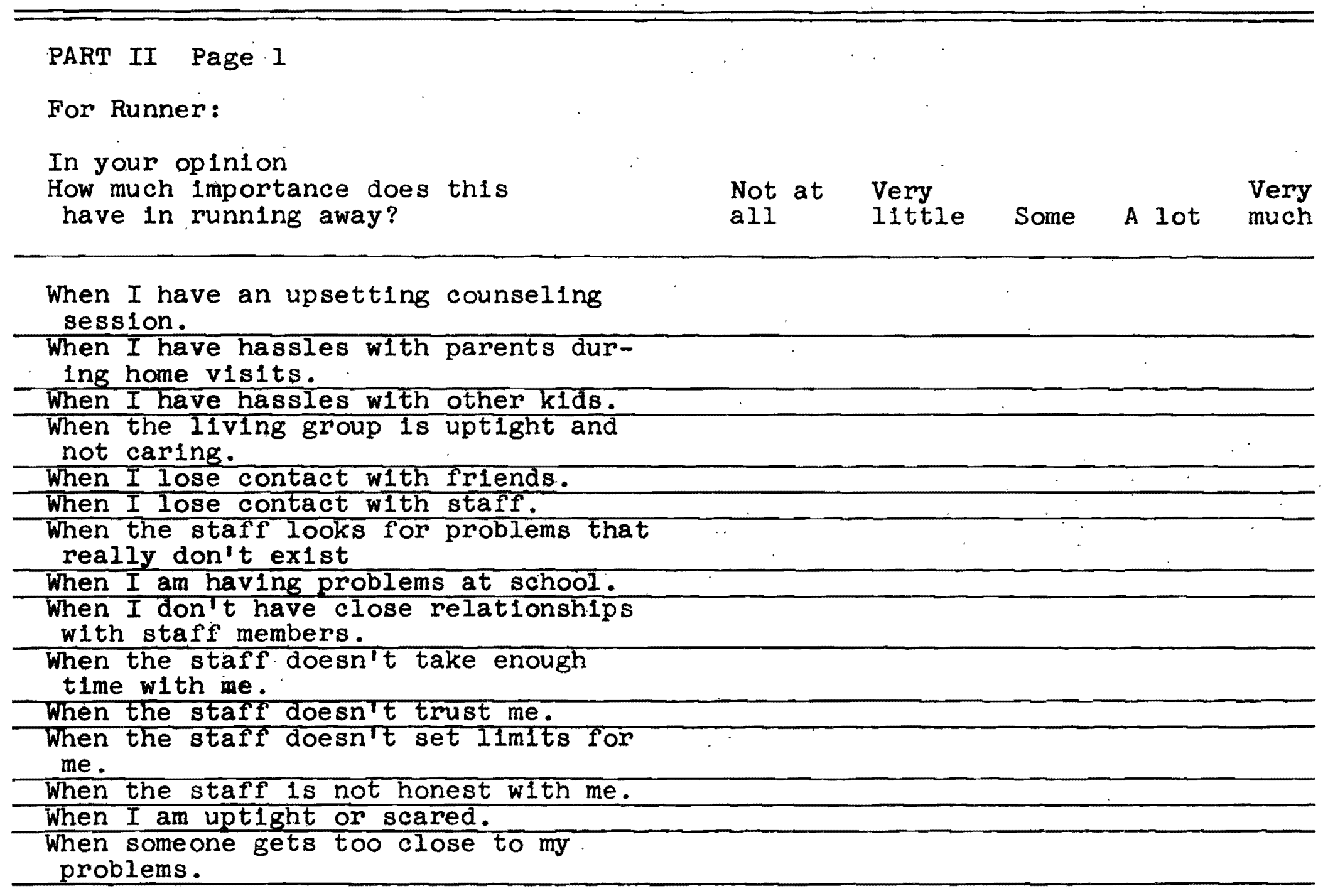


Part II Page 2

For Runner (Continued):

In your opinion

How much importance does this

have in running away?

Not at Very

all

iltie

Some

A 1 ot

Very

much

When I am tempted to get loaded on

drugs.

When I feel a need to have sex.

When I feel depressed.

When I'm not getting help with

problems.

When I feel locked in.

When I am tired of being told what

to do.

When I think I'II get to go home. 


\section{PART II Page 3}

For Nonrunner:

In your opinion

How much importance would this

Not at Very

have in running away?

all

very

Some

A $10 t$

Very

much

An upsetting counseling session.

Hassles with parents during home visits.

Hassles with other kids.

If the living group is uptight and not

caring.

Loss of contact with friends (outside).

Loss of contact with staff.

When the staff is looking for probiems

that really don't exist.

Problems at school.

No close relationships with staff

members.

Staff not taking enough time with kids.

Staff not trusting kids.

Staff not setting limits for kids.

Staff not being honest with kids.

Feeling uptight or scared.

Others getting too close to the kids problems.

Belng tempted to get loaded on drugs.

Feeling a need to have sex.

Feeling depressed. 


\section{Part II Page 4}

For Nonrunner (Continued):

In your opinion

How much importance would this

have in running away?

Not at

all
Very Iittle
Some

A 1 ot
Very

much

Not getting help with problems.

Feeling locked in.

Feeling tired of belng told what do do.

Thinking they'11 get to go home. 


\begin{tabular}{|c|c|c|c|c|c|}
\hline $\begin{array}{l}\text { PART II Page } 5 \\
\text { Kids are most likely } \\
\text { to run during: }\end{array}$ & $\begin{array}{l}\text { Disagree } \\
\text { strongly. }\end{array}$ & $\begin{array}{l}\text { Disagree } \\
\text { somewhat }\end{array}$ & $\begin{array}{l}\text { Ne1ther } \\
\text { agree. } \\
\text { nor } \\
\text { disagree }\end{array}$ & $\begin{array}{l}\text { I agree } \\
\text { somewhat }\end{array}$ & $\begin{array}{l}\text { I agree } \\
\text { very } \\
\text { much }\end{array}$ \\
\hline Spring & & & & & \\
\hline Summer & & & & & \\
\hline Winter & & & & & \\
\hline $\mathrm{Fall}$ & & & · & & \\
\hline \begin{tabular}{lll}
\multirow{2}{*}{ Breaks } & a. & morning \\
& b. lunch \\
& c. & evening \\
\end{tabular} & & , & & & \\
\hline Group outings & & & & & \\
\hline Home visits & & & & & \\
\hline During outside employment & & & & & \\
\hline Just before release time & . & & & & \\
\hline
\end{tabular}




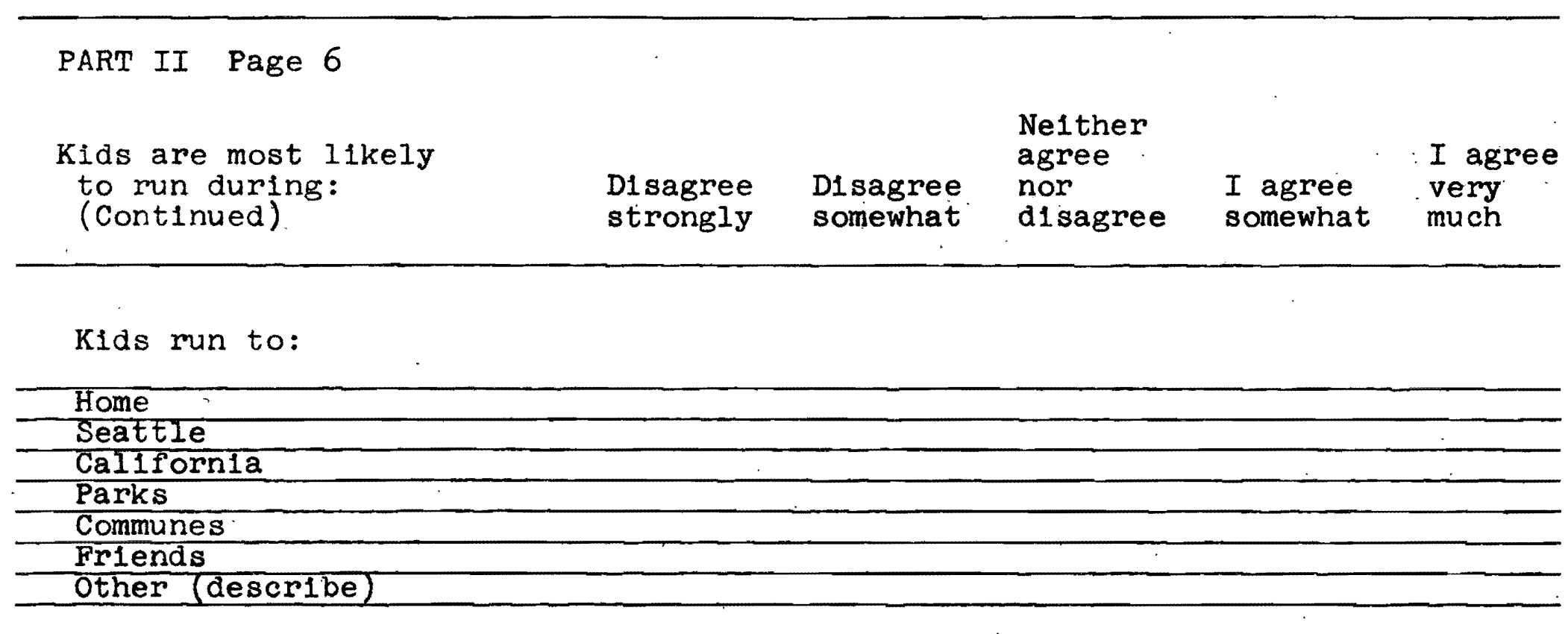




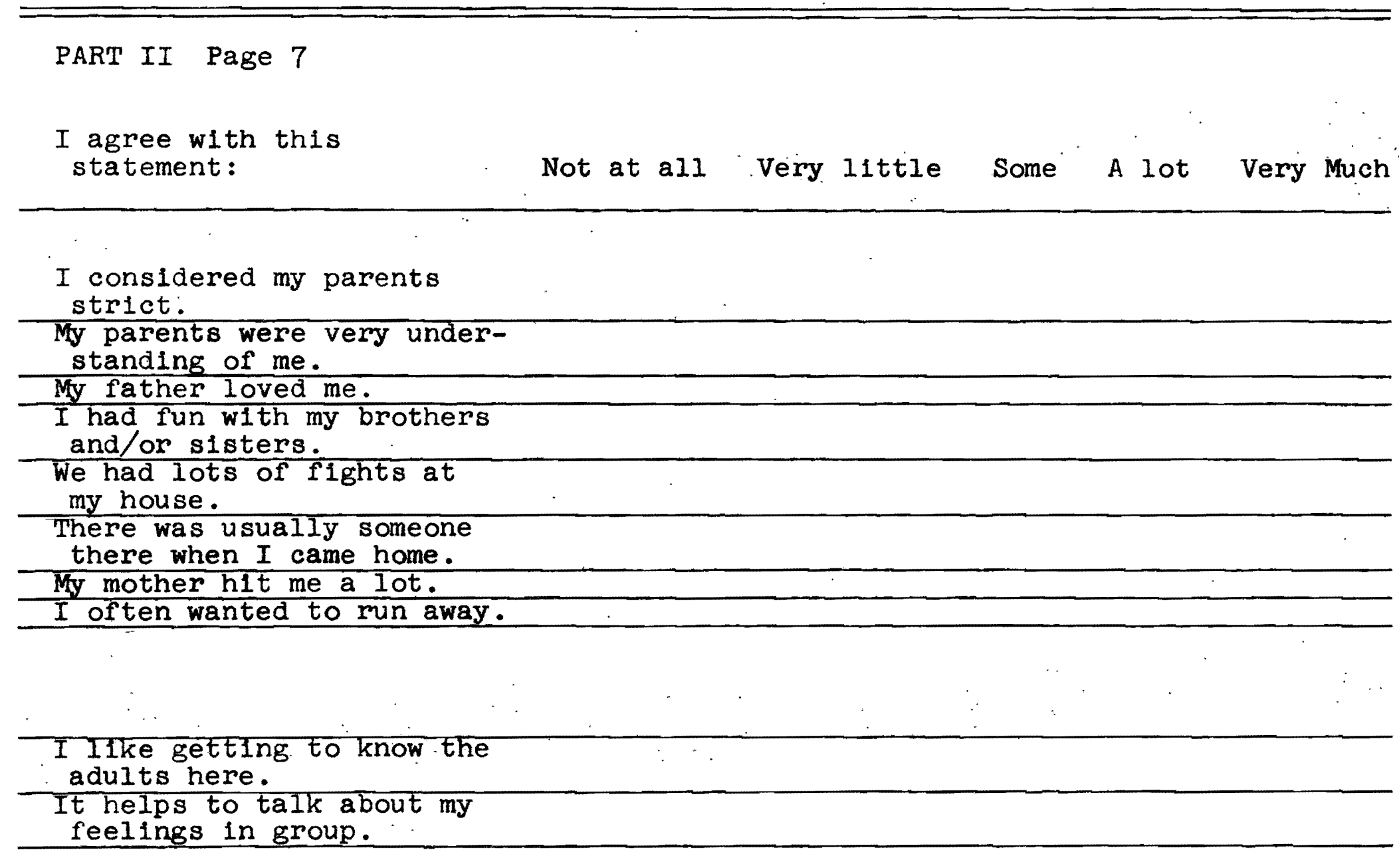




\begin{tabular}{l} 
PART IT Page 8 \\
I agree with this \\
statement: \\
(Continued) \\
\hline \\
I Ilke doing things on \\
schedule. \\
The group outings we have \\
are fun. \\
It's helpful to have some- \\
one around to talk with.
\end{tabular}

